\title{
Sosyal Medya Çağında Dijital Emek Kavramı Ve Ticari Bir Medya Platformu Olarak Google
}

Pinar KARACA ${ }^{1}$

\section{Özet}

Üretim ve dolaşımın günden güne dijital bir hal alması ve ağ mantığına göre biçimlenmesi, emek faaliyetlerinin değişimine sebep olmaktadır. Emek ürünü olarak varsayılan metalar, dijital içerikli hale gelmekte, üretim veya tüketim teknolojileri, en çok da medya endüstrisi, bu süreçte dönüşüm yaşamaktadır. Üretim, maddi olmayan emek üzerine kurulmakta, medya endüstrisi tarafından biçimlendirilmektedir. Sosyal ağlarda yaratılan içerik sistemleri maddi olmayan emek birikimi sonucu, medya endüstrisi tarafından işlenmekte ve kullanıcı verileri, maddi kaygı güden kuruluşlara satılmaktadır.

$\mathrm{Bu}$ doğrultuda çalışmanın amacı, enformasyon ve dijital iletişim teknolojileri aracıllı̆̆yla değişen emek kavramının, sosyal medya çağında nasıl işlerlik kazandığına ve ticari kuruluşların bu emekleri ne şekilde kullandığına dair bilgiler sunmaktır. Durum analizi yapılarak geliştirilen çalışmada; dijital emek kavramı ve gelişim sürecine, üretim ve iletişim aracı olan sosyal medyada sermaye birikiminin ne doğrultuda gerçekleştiğine, sosyal medya platformlarında dijital emeğin nasıl oluştuğuna dair bilgilere yer verilmektedir. Ticari medya platformu olan Google ise dijital emek kavramı açısından ele alınarak, açıklanmaktadır.

Çalışmada, dijital medya kullanıcılarına ait verilerin, medya endüstrisi tarafindan kullanıma açık bir halde olduğu, kişiselleştirilmiş mesajların bu veriler dikkate alınarak oluşturulduğu sonucuna varılmaktadır. Ayrıca kullanılan veriler, artı-değer oluşturmakta ve karşılığı ödenmemiş emek olarak ticari kuruluşların metası haline gelmektedir.

Anahtar Kelimeler: Dijital Emek, Maddi Olmayan Emek, Sosyal Medya, Google.

\footnotetext{
1 Doktora Öğrencisi, İstanbul Ticaret Üniversitesi, Sosyal Bilimler Enstitüsü, Halkla İlişkiler ve Reklamcılık Anabilim Dalı pinar.krcc@ gmail.com Orcid ID: 0000- 0002-8083-3496

Bu makaleye atıf için: Karaca, P. (2021). Sosyal Medya Çağında Dijital Emek Kavramı ve Bir Ticari Medya Platformu Olarak Google. Aksaray Iletişim Dergisi, 3(1), 131-164. doi:10.47771/aid.726025
} 


\title{
The Concept of Digital Labor in the Age of Social Media And Google as a Commercial Media Platform
}

\begin{abstract}
The day-to-day digitalization of production and circulation and its formation according to the logic of the network causes the change of labor activities. Commodities assumed to be labor products become digital content, production or consumption technologies, mostly the media industry, undergo a transformation in this process. Production is based on immaterial labor, shaped by the media industry. Content systems created in social networks are processed by the media industry as a result of immaterial labor accumulation and user data is sold to organizations with financial concerns.
\end{abstract}

In this direction, the aim of the study is to provide information on how the concept of labor that has changed through information and digital communication technologies has come into effect in the age of social media and how commercial organizations use these efforts. In the study developed by conducting situation analysis; Information on the concept of digital labor and its development process, the direction of capital accumulation in social media, which is a means of production and communication, and how digital labor is formed on social media platforms. The commercial media platform Google, on the other hand, is discussed in terms of digital labor concept and explained.

In the study, it is concluded that the data of digital media users are available for use by the media industry and personalized messages are created by taking these data into consideration. In addition, the data used create surplus value and become the commodity of business organizations as unpaid labor.

Keywords: Digital Labor, Intangible Labor, Social Media, Google.

\section{Giriş}

Dijital emek, iletişimin ekonomi politiği alanında önemli tartışma konusu haline gelen bir kavramdır. Çağdaş kurumsal internet platformlarının, baskın sermaye birikimi modelini dikkate alarak içerik oluşturması ve sosyal ağ sitelerini kullanan kullanıcıların; ilişkileri, konum verileri, göz atma verileri, beğeniler ve tercihler hakkındaki tüm verileri, kullanıcıların ücretsiz emeği kapsamında değerlendirildiğinden, bu kavrama dair tartışmalar devam etmektedir. Ayrıca kullanıcıların sosyal ağ sitelerinde gerçekleştirdiği eylemlere uyumlu pazarlama içerikleri geliştirilmekte ve meta olarak satılan veriler varlığını bu şekilde göstermektedir. 
Meta olarak satılan veriler, kullanıcıların sosyal medya platformları ya da internet kullanımlarında gerçekleştirdikleri eylemler sonucu pazarlama stratejilerinin ana hedefi haline gelmektedir. Fakat ticari sosyal medya platformları, kullanıcı verilerini metalaştırırken kullanım koşulları ve gizlilik politikaları geliştirerek kullanıcının onayına sunmaktadır. Sosyal medya platformuna üye olmak isteyen kullanıcı da bu şartları, platform dahilinde içerik üretimi gerçekleştirmeden onaylayarak verilerini medya endüstrisinin kullanımına açık hale getirmektedir.

Açık hale gelen kullanıcı verileri de zamanla işlenerek, bilgi dolaşımının işlerliğine olanak sağlamaktadır. Buna bağlı olarak kullanıcıların sosyal medya ya da internet bağlantılarında kendi rızalarıyla sunduğu veriler, özellikle de satış ve pazarlamanın en temel öğesi olan reklam yaratımında bilginin akışını şekillendirmekte ve yeni reklam tasarımlarının var olmasına izin vermektedir. Reklam yaratım sürecinde dijitalleşen veriler sermaye olarak kabul edilmekte ve verileri aktaran kullanıcılara bu reklamlar sunulmaktadır. Dijital emek kavramı da bu sürecin akışını anlamak adına incelenen bir kavramdır.

Dijital emek kavramının gelişmesinde ve ortaya çıkmasında Marksist emek değer teorisinin ve Marksist emek reklamcılık teorilerinin uygulanması ve geliştirilmesi önemli bir yere sahiptir. Dallas Smythe'ın medya ve iletişimde Marksist politik ekonomisi, yeniden canlandırılmakta ve daha da geliştirilmektedir. Smythe, reklam gelirleriyle finanse edilen gazete, televizyon ve radyo istasyon izleyicilerinin, bu medya araçlarına dikkat kesildiğinde aktif hale geldiğini (izleyici emeği) ve reklamcılara satılmak üzere kendilerini meta olarak (izleyici metas1) ürettiğini belirtmektedir (aktaran Ekman, 2019:109).

Meta olarak medya izleyicisi kavramı, iletişimin ekonomi politiğine ilişkin inceleme alanında çokça tartışmaya konu olmuştur. Smythe'ın (1982) iddiası izleyicinin kitle iletişiminin başlıca metasını oluşturduğu yönündedir (aktaran Mosco, 2009: 136). Smythe'ın geliştirdiği bu kavram, reklamcılarla ilgili olarak medya yapımcılarının, izleyicileri oluşturmadaki rolünü vurgulamaktadır. İzleyicilerin metalaşması, medya örgütlenmelerini, sermaye dolaşımının bütünleşmiş bir bölümü olarak 'topyekün kapitalist ekonomi' içine yerleştirmektedir (Mosco, 2009: 137).

Fuchs'a göre (2015:143), internetteki ticari platformların kullanıcı faaliyetlerini sömürmesini tarif etmek için Smythe'ın izleyici metası kavramını ele almak olağandır ve bu anlamda internette üreten tüketici anlamına gelen üretüketici, kavramını literatüre eklemektedir. Fuchs 
ve Mosco, Dallas Smythe'ın izleyici metası kavramı üzerinden yürütülen dijital emek çalışmalarına yoğunlaşmaktadır. Pek çok araştırmacı da Smythe'ın izleyici metası kuramının Facebook ya da YouTube gibi platformlarda dijital emeğin uygulanabileceğine dair açıklamalarda bulunmaktadır.

İnternet ekonomi politiğine konu olan dijital emek kavramı, farklı araştırmacılar tarafindan ele alındığından çeşitli tanımlamalar barındırmaktadır. Çalışmada, kavramın daha açık bir şekilde tanımlanması adına üretim ve iletişim aracı olan sosyal medyada sermaye birikim biçimleri incelenmekte ve sosyal medyada dijital emeğin nasıl ve ne şekilde meta haline getirildiği açıklanmaktadır. Ayrıca çalışmada, ticari medya platformu olan Google'ın gelişim sürecine, kuruluş politikasına, iş birliklerine, kullanıcıları nasıl konumlandırdığına dair bilgiler verilmektedir. Kullanıcı aramalarının ve bilgi edinimlerinin ücretsiz bir şekilde gerçekleştirileceğini ifade eden ve politikalarını bu yönde geliştiren arama motoru, ticari potansiyelini de göz ardı etmeyerek, emek gücüne ve sermaye birikimine odaklanmaktadır. Ayrıca meta haline gelen kullanıcı verileri belirli reklam şirketlerine satılarak, geliştirilen işlemlerle tekrar kullanıcıya iletilmektedir. İletimler neticesinde de kullanıcının, satın alma eyleminde bulunması beklenmektedir.

Çalışma kapsamında ele alınan konular dijital medya ve sosyal ă̆ kullanıcı verilerinin kategorize edildiği, buna bağlı olarak da kişiselleştirilmiş mesajların bu veriler dikkate alınarak tasarlandığı, reklamverenlerin reklam stratejilerini bu doğrultuda gerçekleştirdiğine dair bilgilere ulaşılmaktadır. Google, kullanıcı verilerini metalaştırarak ticari kuruluşlara sunmakta, kişiselleştirilmiş iletilerle her an her yerde Google ile karşılaşmak mümkün hale gelmektedir. Platformun veri koşulları ve politikaları da kullanıcı verilerinin kullanıma açık olduğunu belirtir nitelikte geliştirilmekte, bu sebeple yasal süreçte kullanıcının onayı olduğundan veri ihlali söz konu görülmemektedir. Kullanıcı verileri, sorunsuz bir biçimde artı-değer oluşturmak için işlenmekte ve karşılığı ödenmemiş emek olarak ticari kuruluşların metası haline gelmektedir.

\section{Dijital Emek Kavramı ve Gelişim Süreci}

Hard ve Negri, dünya tarihinde var olan ekonomik paradigmaları inceleme alanlarına dahil ederek, çağın kolektif örgütleniş biçiminde önemli rol oynayan bir modeli ortaya koymaktadır. İkili, baskın olan sektörler bazında ekonomi bakımından üç ana süreçten bahsetmektedir: İlki tarıma ve hammadde çıkarılmasına, ikincisi endüstri ve dayanıklı malların üretimine ve üçüncü de hizmet ve enformasyon üretimine dayanmaktadır. İlk süreçten ikinci sürece kadar yaşanan değişiklik ekonomik modernleşmeyi, ikinci süreçten üçüncü sürece kadar yaşanan geçişse, 
ekonomik post-modernleşmeyi ya da enformatikleşmeyi ifade etmektedir. Ekonomik postmodernleşmenin oluşmasını sağlayan ana etmenlerden biri de üretimde post-Fordist düzene geçilmiş olmasıdır.

Hard ve Negri'ye göre (2002: 42), post-Fordizm: Enformasyona bağl1, üretimin merkezi hale geldiği, büyük ölçüde de maddi olmayan emeğin belirleyici olduğu modern ekonomiden postmodern ekonomiye geçiş sürecini ifade eden bir üretim rejimi olarak ifade edilmektedir. Hard ve Negri tarafindan 'ekonominin post-modernleşmesi' olarak ifade edilen süreç, bilgisayar metaforuyla açıklanmaktadır. Bilgisayar metaforu sonucu, enformatikleşme ile beraber endüstriyel üretim faaliyetlerinin öneminin azaldığı fakat baskı teknik sayılarının ve yoğunluğunun arttığı belirtilmektedir (Özmakas, 2015: 13). Buna bağlı olarak, endüstriyel üretim zamanla yerini hizmet sektörüne bırakmaktadır. Fakat bu değişim, endüstriyel üretim faaliyetlerinin veya emek faaliyetlerinin yok olması anlamına gelmemektedir.

Aksine bu durum 'imalatın hizmetleşmesi' olarak şekillenmekte ve bu anlayışın baskın bir hal alması söz konusu olmaktadır. Post-Fordizmi biçimlendiren bu anlayış, emeğin üretim şeklinde, emekçi ve emeğin özünde çeşitli değişiklere sebep olmaktadır (Özmakas, 2015: 14). Ayrıca bu yaklaşıma göre, emeğin üretilmesi adına kurulan fabrika gibi yapılara ihtiyaç duyulmamaktadır. Buna bağlı olarak, emek üretimi için fiziksel mekanlara ihtiyaç duyulmamakta ve fabrikaların olmayışı doğal olarak emeğin denetim mekanizmasını da değiştirmektedir. Endüstriyel üretimin bizzat kendisine enformasyon çıtılarını model olarak alması sonucu, yeni emek türleri ortaya çıkmaktadır.

Ortaya çıkan emek türlerinden en önemlisi de enformatikleşme aşamasında önemli yer edinen, 'maddi olmayan emek'tir. Hizmet üretimi, somut bir ürün ya da kalıcı bir mal ortaya koyamadığından, bu üretim ile ilgili emek, maddi olmayan emek olarak adlandırılmaktadır. Maddi olmayan emek: Bir hizmet, bir kültürel ürün, bilgi veya iletişim benzeri maddi olmayan mallar üreten emek olarak tanımlanmaktadır (Hard ve Negri, 2002: 303). Bu kavram, Hard ve Negri tarafından İtalyan Otonomistlerinin 1960 ve 1970'li yıllar arasında mevcut olan tartışmalarından $^{2}$ esinlenilerek oluşturulmuştur. Fakat bu kavramı 19. yüzyılda ilk kez ifade

\footnotetext{
2 İtalya'da işçi sınıfı üzerine yapılan araştırmalar sonucu sermayenin teknolojik gelişmelerle şekillendirmeye çalıştığı emek biçimleri, İtalyan sol entelektüel isimler tarafından tartışılmış ve bu konuda yeni bir işçi politikası oluşturma çabasına gidilmiştir. Politika temelde sermayenin bir parçası haline gelen işçi emeğini, var olduğu yerden kurtarmaya çalışmaktadır. Ayrıca işçi sınıfının teknolojinin ilerlemesiyle sermayenin bir parçası olarak örgütlenme biçimlerinden kazanım sağlamama durumu tartışılmaktadır (Uca, 2018: 1143).
} 
eden kişi, Henry Storch’tur (Haug, 2009). Her ne kadar Storch, kavramı ilk kez dile getiren kişi olsa da bu kavramı geliştiren kişi, İtalyan Otonomist hareketinin önemli bir ismi olan Maurizio Lazzarato’dur (Özmakas, 2015). Lazzarato'ya göre (1996: 145) maddi olmayan emek:

Emeğin iki farkl yönüne işaret etmektedir: Metanın enformasyonel içeriği bakımından maddi olmayan emek, dolaysız emek adına zaruri olan becerilerin yükselen biçimde sibernetik ve bilgisayar hakimiyetine dair beceriler gerektirdiği endüstri sektörü ve üçüncü sektörlerdeki büyük şirketlerde çalışan işçilerin, emek süreçlerinde gerçekleşmekte olan değişimlere doğrudan gönderme yapmaktadır. Bu durumun haricinde maddi olmayan emek, kültürel içeriğini üreten faaliyet bakımından, normalde iş olarak kabul görmeyen birçok eylemi içermektedir. Yani maddi olmayan emek; kültürel ve sanatsal standartlara, modaya, zevklere, tüketici normlarına ve stratejik olarak kamuoyunu belirlemeye ve korumaya yönelik etkinlerdir.

Lazzarato'nun maddi olmayan emek tanımına bağlı olarak, sadece üretim ve emek bakımından yeni bir durumun ortaya çıkmadığı görülmektedir ve öznellik üretiminde de yeni bir aşamadan söz edilmektedir. Örneğin, sosyal medya ağlarının ilk önce kullanıcının profil oluşturmasını talep etmesiyle "özne olmaya” adım atılması sağlanmaktadır (Coté ve Pybus, 2011: 170). Bu talep basit şekilde maddi dünya akışındaki öznelliğin sanal dünyaya aktarılması halinde meydana gelmemektedir. Bunun nedeni ise gerçek dünya ile sanal ortam arasında benzer eylemlerin söz konusu olmamasıdır. Sosyal ağlar, benzerliğin aksine toplumsal bir fabrika olarak işlerlik kazanmakta ve bu fabrikalarda dijital emek üretimi adına faaliyetler geliştirmektedir. Üretilen bu emekler, profil takipçilerini potansiyel bir müşteriye, profile sahip olan kullanıcıyı da bir satıcıya dönüştürme eğilimindedir.

Kalıcı bir meta üretmeyen maddi olmayan emek; fikirler, semboller, kodlar, içerikler, dilsel imgeler, imajlar benzeri ürünler üretmektedir (Hard ve Negri, 2004:122). Bu model, bilgisayar modeli ile açıklanmaktadır çünkü temel olarak emek enformasyon ve iletişim teknolojileriyle ilişkili görülmektedir (Hard ve Negri, 2002: 305). İletişim teknolojileriyle ilişkili görülen maddi olmayan emek, ağ toplumunun faaliyetleri ve emek üretimi neticesinde dijital emek kavramıla da adlandırılmaktadır. 
Dijital emek, enformasyon ve iletişim teknolojileri alanında sermaye birikiminde gerekli olan karşılığı ödenmemiş kullanıcı emeğinin ve emeğin diğer şekillerinin analizine odaklanmaktadır (Fuchs, 2016: 92). Birçok araştırmacı dijital emeği, sosyal medya kullanıcıları tarafından gerçekleştirilen karşıllı̆ı ödenmemiş emek olarak nitelendirse de Fuchs, sosyal medyada var olan tüketen üreticinin dijital emeğin yalnızca belli bir şeklini ortaya çıkardığını, bu şeklin dijital medyanın varlığını oluşturan küresel sömürü ekolojisini gerçekleştiren diğer biçimleriyle bağlantılı ve onlara bağlı olan bir şekil olduğunu vurgulayarak, bu alandaki emek süreçlerini tarif etmeye çalışmaktadır. Fuchs, "dijital emek" kavramını, dijital medyanın var olması, üretilmesi, yayılması ve kullanılması için gerekli olan karşılığ tüm emek biçimlerini içerecek şekilde açıklamaktadır (aktaran Saraçoğlu, 2015: 15).

Dijital emek tartışmaları, Dallas Smythe çalışmalarının yeniden incelenmesiyle ve önem arz etmesi sonucu geliştirilmiştir. Smythe'ın savunmasında: Reklam gelirleriyle finanse edilen gazeteler, televizyon ve radyo istasyonları izleyicilerinin, bu medya araçlarına dikkat kesildiğinde çalıştığını (izleyici emeği) ve reklamcılara satılmak üzere kendilerini meta olarak (izleyici metası) ürettiği belirtilmektedir (Ekman, 2019:109). Meta olarak medya izleyicileri kavramı, iletişimin ekonomi politiğine ilişkin inceleme alanında pek çok tartışmaya zemin hazırlamıştır. Temel unsur, izleyicinin kitle iletişiminin başlıca metasını oluşturduğu yönündedir (Mosco, 2009:136). Smythe'ın geliştirdiği bu kavram, reklamcılarla ilgili olarak medya yapımcılarının, izleyicileri oluşturmadaki rolünü vurgulamaktadır. İzleyicilerin metalaşmas1, medya örgütlenmelerini, sermaye dolaşımının bütünleşmiş bir bölümü olarak “topyekün kapitalist ekonomi” içine yerleştirmektedir (Mosco, 2009: 137).

Ayrıca medya sahipleri adına iş yapan -televizyon izleyen- izleyici düşüncesi, ekonomi politiğin içinde kapsamlı bir şekilde tartışma konusu olmuştur. (Mosco, 2009: 137). Bolin (2011: 37), televizyon izlemenin "işçinin emek gücünün tekrar yaratımının bir parçası" olarak kavranabileceğini önermektedir. Televizyon izlemek, bir şey üreten bir eylem değildir, reklamcılar ve medya şirketleri tarafından yerine getirilen üretim aşamasında "hammadde" olarak tanımlanabilecek bir süreçtir. Sonuç olarak, televizyon izlemek üretim araçlarının parçası halindedir fakat emek olarak değerlendirmek doğru değildir.

Mosco, Smythe'ın emek oluşturan izleyici savının yararlı olup olmadığını bir kenara bırakılıp bırakılmayacağını sorgulamaktadır. Mosco’ya göre (2009: 137), Smythe'ın kuramındaki materyalist yaklaşımda sunulan temel unsur "medya şirketi- izleyici ve reklamcı karşılıklı ilişki" kavramıdır. Kitle iletişiminin yalnızca ideoloji üreticisi ve yayıcısı olmakla kalmayıp ayrıca 
sermayenin dolaşımıyla bütünleşmiş olduğu fikri, kitle iletişimin ekonomi politiğinin konularına dahil edilmektedir.

Janet Wasko (2005: 29), “özelleştirilmiş, reklamcı destekli medyanın artan yayılımıyla izleyici metası kavramının, pek çok ekonomi politikçinin yanı sıra diğer iletişim kuramcıları tarafından da benimsendiğini” ileri sürmektedir. Bu eğilim son yıllarda artış göstermekte ve Dallas Smythe'ın özellikle ticari "sosyal media" kullanıcılarının işçi olup olmadıkları ve sömürülüp sömürülmedikleri sorusuna dair çalışmalara olan ilgi artmaktadır. Terranova (2000: 33), "dijital emek" tartışmasına dair katkıyı, ücretsiz internet emeği kavramı ile yapmıştır: Aynı anda, gönüllü olarak verilen ve ücretlendirilmeyen, sahip olunan ve sömürülen internetteki ücretsiz emek, web siteleri kurmayı, yazılım paketlerini değiştirmeyi, e-posta listelerini okumayı, listelere katılmayı ve sanal ortamlar inşa etmeyi kapsamaktadır. Terrenova, ücretsiz emek kavramını, Otonomcu Marksist kavramı olan maddi olmayan emeğe bağlamıştır fakat Dallas Smythe’ın izleyici emeği kavramıyla olan ilişiğini düşünmemiştir (Fuchs, 2015: 143).

Fuchs, çalışmalarında internetteki ticari mecraların kullanıcı faaliyetlerini sömürmesini tarif etmek için, Smythe'ın izleyici metası kavramının uygun olduğunu vurgulamakta ve bu anlamda üretüketici kavramı üzerinde durmaktadır (2015:143). Üretüketici kavramı ise tüketicilerin, tüketim kazanımını sağlamak için katıldığı süreç dahilinde, bir çeşit hizmet üreticisine dönüşme hali olarak tanımlanmaktadır (Ritzer ve Rey, 2016: 171). Buna bağlı olarak yaşanan aktivitenin, duygulanımsal yönlü bir çalışma şekli olduğu görülmektedir. Ancak aktiviteyi yürütenler tarafından işi yapma ve işe sevk edilme durumu emek olarak algılanmamaktadır.

Algılanmamasının nedeni ise kişilerin (tüketicilerin) işe sevk edildiklerinin farkında olup yapılan işi, gerçekleştirilen tüketim kazanımının ritüeli olarak kabul etmesidir. $\mathrm{Bu}$ nedenle üretüketiciler, ücreti ödenmeyen bir iş yaptıklarında, bu durumu kapitalist sisteme hizmet olarak algılamamaktadır. Ancak gerçekleşen eylemler çalışma özelliği taşımakta ve meydana gelen işe yönlendirilme durumu da emek şekline dönüşmektedir (Çetin, 2019: 365).

İnternetin gelişimi ve yaygınlaşmasıyla birlikte de tüketicilerin işe yönelme eğilimi, ağ tabanlı erişim alanına doğru genişlemektedir. Sosyal medya mecralarında kullanıcı kaynaklı içerikler, tüketilirken üretilen davranışların izlerini taşıyan uygulamalar olarak analiz edilmektedir. Buna göre üretüketim ve benzeri kavramlar araştırılırken, uygulamaların ne olduğunu açıklamak gerekmektedir (Ritzer ve Rey, 2016: 160). 
Vince Manzerolle (2010)'da mobil izleyici metası kavramını uyguladığı mobil internet üzerindeki kullanıcı verilerinin metalaşma analizini, bu analize ve Smythe'ın çalışmalarına dayanarak gerçekleştirmektedir. İnternet üretüketicisi gerçekliğini ampirik olarak test ve analiz eden Sandoval (2012: 164-165), web platformlarının \%90'dan fazlasının hedefli reklamcılık kullandığı, kullanıcı verilerini gözetim altına aldığı ve metalaştırdığı sonucuna varmıştır. İnternet üretüketicisinin metalaşmasını yasallaştırarak garanti altına alan hükümler ve ilkelerin analizi; bunların "kafa karıştırıcı, yanıltıcı, ideolojik ve hatta manipülatif” olduğu gerçeğini göstermektedir. Hüküm ve ilkeler dikkate alındığında platformların tek amacı, kullanıcılara ilgi çekici ve yüksek kaliteli bir servis sağlamak, onlara kendi medya içeriklerini üretmek ve arkadaşlarıyla bağlantı kurma deneyimi yaşatmak olduğu izlenimini yaratmaktır. $\mathrm{Bu}$ platformlar, kullanıcı verilerini ve saklı kalan reklam alanlarını satışa sunarak, gelirlerini artırmayı hedefleyen ticari şirketlere aittir.

Vincent Mosco (2009) ise Smythe'in izleyici metasıyla ilgili bir tartışmada, her enformasyon işlemini eksiksiz olarak ölçen ve takip eden dijital sistemlerin; seyirciyi, dinleyiciyi, okuyucuyu, bilgisayar ve telefon kullanıcılarını reklamcılara teslim etme aşamasını geliştirmek adına kullanıldığını ifade etmektedir. İnteraktif sistemler, tüketici davranış profillinin kapsamlı olarak derlenmesine imkan sağlamakta ve bu durumda zevk ve gelirlerine göre kategorileştirilen tüketicilerin hedeflenmesini her zaman olduğundan daha titizlikle yapmaktadır (DyerWintheford, 1999: 118). Dyer-Wintheford (1999: 119), Smythe'ın sermayenin planlanmış izleyici sömürüsü gücünün tam olarak başarılı olduğu varsayımını çok fazla kullanmasını eleştirmekte ve online korsanlık ve alternatif medya gibi faaliyetlerin, sermaye gücünü kırma girişimleriyle eşdeğer olduğunu söylemektedir.

Cohen (2008: 8), Smythe'ın esasen web 2.0 içerik üretiminde yer alan emeğin; enformasyon, sosyal ağlar, ilişkiler ve duygulanımlar ürettiğini varsaymaktadır. Coté ve Pybus (2010) ise internette izleyici emeğinin bahsedilemeyeceğini; bu sebeple maddi olmayan emek 2.0 terimini kullanmayı tercih ettiklerini ifade etmektedir.

Christian Fuchs ve Vincent Mosco, Dallas Smythe'ın özellikle dijital emek tartışmasına dair çalışmalar gerçekleştirmektedir. Pek çok araştırmacı da Smythe'ın izleyici metası kuramının Facebook veya Youtube gibi mecralardaki dijital emeğe uygulanabileceğine dair açıklamalarda bulunmaktadır. Araştırmacıların ortak savı ise dijital emeğin sermaye tarafından sömürüldügüüür. Dijital emeğin sömürüsü de üç unsurda toplanmaktadır Fuchs, 2015: 146147): 
1. Baskı: İletişimde, paylaşımda, içerikte bulunmak ve toplumsal ilişkilerini sürdürmek isteyen kullanıcılar, ticari medya platformları tarafindan baskı altına alınmaktadir.

2. Yabancılaşma: Platformlara ve yaratılan gelirlere kullanıcılar değil, şirketler sahip olmaktadir.

3. El Koyma: Kullanıcılar, sermaye birikimi modelleri tarafindan finanse edilen ticari internet platformlarında zaman geçirmektedir. Kullanıcıların ticari platformlar üzerinde geçirdiği zaman, karşıllğg ödenmeyen dijital emekleri tarafindan yaratılan değerlerdir. Kullanıcıların dijital medya platformlarında geliştirdiği; toplumsal ilişkiler, profil bilgileri, içerikleri ve tarama davranışları, hedeflemeye çalıştı̆̆ı tüketiciyi belirlemek isteyen reklamveren işletmeler için internet şirketlerinin satılı̆̆a çıkardı̆̆ bir veri metası haline dönüşmektedir.

Metalaştırmanın, ticari sosyal medya platformlarında nasıl gerçekleştiğine dair bilgiler vermek, sürecin nasıl işlediğini net bir şekilde gösterecektir. Bu sebeple üretim ve iletişim aracı olarak kullanılan sosyal medyada sermaye birikiminin ne şekilde işlediğini açıklamak gerekmektedir.

\section{2. Üretim ve İletişim Aracı Olan Sosyal Medyada Sermaye Birikimi}

Sermaye "maddi bir yatırıma dönüşmeli"dir" (Arthur, 1998: 117). Bunun nedeni ise sermaye birikimi kapsamında kapitalistlerin, birikimin bir bölümüyle tekrar yatırım yapacakları, parasal kâr elde etmek amacıyla satmayı düşündükleri yeni metaların üretimini gerçekleştirecekleri, emek gücü ve üretim araçları satın almalarıdır. Marx'a göre sermaye birikimi ikiye ayrılmaktadır, dolaşım alanı ve üretim alanı. Dolaşım alanında sermaye kendi değerine dönüşmekte ve dönüşümde ilk önce para, metaya dönüşür, -alıcı olarak kapitalist sistem yönünden- ve kapitalist, emek gücünü, üretim araçlarını, metaları satın alarak dolaşım sürecini başlatmaktadır (aktaran Fuchs, 2015: 147)

Bu durum şu anlama gelmektedir: Özel mülkiyet anlayışından dolayı işçiler, üretim araçlarının, ürettikleri ürünlerin ya da oluşturdukları kârın sahibi konumunda değildir, bu kaynaklara kapitalistler sahip olmaktadır. Üretim alanlarında yeni bir ürün üretilirken ürüne, emek gücünün değeri ve üretim araçlarının değerleri de eklenmektedir (Fuchs, 2015: 147).

Marx'a göre (1978: 132), sermaye bir çevrimdir, çünkü belli oranda değerin birbirine karşılıklı olarak bağlı üç başkalaşımdan oluştuğu bir sıralamadan geçmesine imkân tanınmaktadır. $\mathrm{Bu}$ süreçten geçerken değer, hem kendini korumakta hem de büyüklüğünü artırmaktadır. Her biri sıralamadan geçerken, sermaye bir dolaşım sağlamakta ve bu aşamayı yeniden tekrarlamaktadır. 
Sermaye çevrimi üç aşamada gerçekleşmektedir: Üretim alanı, dolaşım ve sermayenin üç özel biçimi (para, meta ve üretken sermaye). İlk aşama, ödeme ya da satın alma aracı olarak paranın işlevini, emek gücü (Eg) ve üretim aracı (Üa) edinmek için kullanılması, ikinci aşama, metaların üretken sermaye (Ü) olarak harekete geçmesi ve üretken biçimde tüketildiğinde işlevini yerine getirmesi, üçüncü aşama ise metanın alınıp satılma eylemi gerçekleştirildiğinde tamamlanmaktadır (Manzerolle ve Kjøsen, 2019: 226). Buna bağlı olarak üretimde artı-değer oluşturma ve ilk aşamadaki sermaye birikimini gerçekleştirme durumu mümkün olmaktadır.

Karşılığ1 ödenmeyen emek, artı-değer ve kâr üretmektedir. Artı-değer, çalışma zamanının karşılığı ödenmeyen bölümüdür. Bu bölüm, iş zamanının (saatlerle ölçülen), kâr elde etmek için kullanılan bölümüdür fakat kâr çalışana değil, kapitalistlere aittir. Kapitalistler, artı-değer için fiyat ödememektedir. $\mathrm{Bu}$ nedenle de art1-değer üretimi, bir sömürü süreci olarak açıklanmaktadır. Üretim sonrası meta, üretim alanını terk etmekte ve sermayenin tekrar dönüşüme izin verdiği dolaşım alanına girmektedir. Meta, piyasada satışa sunularak, meta şeklinden yeniden para biçimine dönüşmektedir. Tek bir aşamanın son noktası olan para, yeni bir birikim aşamasının başlangıç noktası haline gelmektedir. Buna göre sermaye, artı-değerin sömürüsü sebebiyle sürekli artan para olarak değerlendirilmektedir (Fuchs, 2015).

Art1-değer, karşılığ1 ödenmemiş emek zamanının maddeleşmiş halidir. Sermaye değerlendirmesindeki sır ise diğer insanların belirli nicelikteki karşılığı ödenmeyen emeklerini, kendi emirleri altında tuttuğu gerçeğinde yatmaktadır (Marx, 2015: 672). Art1-değer üretimi, kapitalist üretimi diğerlerinden ayıran ve kapitalist aşamanın itici gücü ve en son ürünü olarak betimlenmektedir (Marx, 2015: 976).

Birçok ticari sosyal medya mecrası, kişisel kullanıcı bilgilerine ve davranışlarına uygun hale getirilen hedefli reklamcılığın yardımıyla, sermaye birikimini gerçekleştirmektedir. Bu süreçte kapitalist sistem, daha fazla sermaye birikimi arayışında olmaktadır. Bunu başarmak adına da ya çalışma günlerini uzatma (mutlak artı-değer üretimi), ya da emek üretkenliğini artırma (göreli art1-değer üretimi), eyleminde bulunmak zorundadır. Göreli art1-değer üretimi, üretkenlik artışının ayrıca eskiye göre daha çok meta ve artı-değer üretebilmesini sağladığı anlamina gelmektedir (Fuchs, 2015: 150).

Ne kadar boş zaman yaratılırsa, bireyin o kadar üretkenlik kapasitesi artmaktadır. Önemli olan şey ise boş zamanın, bireylerin ve kültürlerin daha fazla gelişimine ve ihtiyaç çeşitliliğini yaratan bir kültürlenme sürecine izin vermesidir. Art1-değerin, gerekli emek ve artı emek 
arasındaki oranı yükseltmek adına boş zaman üretimine dayanması sebebiyle, sermaye kültürel etkinliklerin fazlalaşmasına izin verip genel olarak boş zaman yaratmakta ve bunun bir neticesi olarak da kültür endüstrisi tarafından değişik şekillerde üretilen birtakım gereksinimlerin genişlemesi sayesinde oluşan artı-değer olarak sermaye, serbest bir şekilde dolaşabilmektedir (Manzerolle ve Kjøsen, 2019: 238-239).

İhtiyaçların çeşitlenmesi ve boş zamanın gelişmesine bağlı olarak, gündelik yaşamda dolaşımın içine dahil edilecek ve dolaşımın genişlemesine katkı sağlayacak yeni alanlar yaratılmaktadır. Leopoldina Fortunati'ye göre (2007: 517), her an her yerde var olan mobil medya, gündelik yaşamın çalışmadan arta kalan zamanlarını ve boş anlarını iletişimsel kullanımın olası yeni anlarıyla doldurmaya yardım etmektedir. Sayısal medya tarafından insani yetilerin yoğunlaştırılmış teknolojik dolayımı, kullanıcıların ücretsiz emeğinin sömürüsüne sebep olmaktadır (Zwick vd., 2009).

Web 2.0'ın gelişimi, sermaye dolaşımında artan ve giderek gereklilik haline gelen ücretsiz emek girdisini kanıtlamaktadır. Boş zamanda karşılı̆̆ı ödenmeyen emek, sermayenin sarmalanan hızlanma algoritmasını denetim altına almak için çabalamaktadır. Enformasyon ve iletişim teknolojileri tarafindan üretilen boş zamanda insani özellikler (bilişsel, yaratıcı, duyuşsal), sermayenin dolaşımını hızlandırmak için kullanılmaktadır (Stiegler, 2010). Bu sermaye birikimi de kişisel veri yı̆̆ının yaratımıdır (Manzerolle ve Smeltzer, 2011).

Kişisel verilerin, kurumlara özgü veri tabanları tarafından ayrıştırıldığı dönemin aksine, kişiselleştirme ve her an her yerde bağlanabilirlik dönemi, sadece kişisel verilerin niteliğinde ve niceliğinde katlanıp büyümekle kalmaz aynı zamanda kullanıcı ve konum üzerinde de -daha çok da mobil cihazlar üzerinde- verilerin kendiliğinden dizin oluşturmasına izin verir (Manzerolle ve Kjøsen, 2019: 242). Sut Jhally (1987: 78) ise "izleyici gözetimi kavramını demografik bakımdan tekrar organize etmenin" bir tür göreli art1-değer üretimi olduğunu savunmaktadır. Hedefli internet reklamcılığı da göreli artı-değer üretiminin bir türü olarak değerlendirilmektedir.

Geleneksel medyada yayınlanan reklamlar, izleyicilere yalnızca tek bir reklam göstermektedir. Fakat hedefli internet reklamcılığında reklam kurumları, farklı reklam yaratımlarını aynı anda sunma özelliğine sahiptir. Bu sayede reklamcılığın faaliyeti artmakta: reklamcılar aynı zaman diliminde hedefli olmayan reklamcılığa oranla tüketici ilgilerine uyması mümkün olan daha fazla reklamı göstermektedir. Bu reklamlar sonucunda elde edilen kâr, kullanıcı tarafından 
gerçekleşen verilerin ve işlem verilerinin kullanılması, kısmen reklam kurumlarının ücretli emekçileri, kısmen de internet kullanıcılarınca üretilmektedir (Fuchs, 2015: 150-151).

\section{3. Üretim Çıktıları: Dijital Metalar}

Küresel açıdan incelendiğinde, iletişime dayalı üretim ve dolaşım aşamalarının birkaç büyük şirket tarafından şekillendirildiğgi bilgisine ulaşılmaktadır. Bunun nedeni ise şirketlerin piyasayı; olabildiğince büyütmek, kontrolü altına almak, ve üretim dolaşım zincirinin bütün halkalarını denetim altına alma hedefiyle, yatay, dikey çapraz ve ultra çapraz bütünleşmelere bağlı olarak tekelleşme eğilimi gösterip küresel ölçekli yapılar haline getirmek istemeleriyle doğrudan bağlantılıdır (Adakl1, 2014; McChesney, 1999:15 vd.: 78). Garnham (2000: 52), bu durumu şirketler bakımından piyasada "hayatta kalmanın temeli" olduğunu ifade etmektedir. Çağdaş dijital iletişim ortamlarında ise farklı medya platformları arasında kurulan yakınsallık ${ }^{3}$, üretim, dolaşım ve tüketim araçlarının iyi şekilde işleyebilmesi adına farklı şekilde hizmet veren şirketlerin mevcudiyetini gerekli kılmaktadır. İletişimsel içeriklerin kendine has özellikleri de dağıtım sürecinde farklı türden altyapı, ekipman ve tüketim aşamasında birbirini tamamlayan ürünleri zorunlu hale getirmektedir (Başaran, 2005: 238).

Buna bağlı olarak, alanda internet, telekomükasyon ve bilgi iletişim sistemleri sektörlerinde faaliyet gösteren şirketler mevcut durumdadır. Bilgi ve iletişim teknolojileri sektöründe; Apple, IBM, Microsoft, Samsung, Oracle, NTT vs. şirketler yerini almakta, internet alanında da Google, Yahoo, AOl ve ayrıca sosyal paylaşım platformları olan; Facebook, Twitter gibi şirketler bulunmaktadır. Bu şirketler; donanım, içerik ve hizmet alanında üretim gerçekleştirip çeşitli metalaşma sürecini başlatmakta, aynı zamanda alt yapı yatırımıyla dolaşım ağında konumlandirılmaktadır (Kiyan, 2015: 35).

Şirketler, içeriğin kendine özgü üretim ve dolaşım aşamalarını başarılı bir şekilde yönetmek için gerekli üretim araçlarına ve emek gücüne yatırımda bulunmakta, üretimi hayata geçirmek üzere çeşitli stratejiler geliştirmekte ve üretim çıtılarını değiş-tokuş aşamasına dahil etmek adına dolaşım alanını kontrolü altına almaktadır (Kıyan, 2015: 36). Thompson'a göre (2008: 124), büyük şirketlerin pek çok medya endüstrisi alanında var olan egemenlikleri, birçoğu alt sözleşmeler ve taşeron düzenlemeler sonucunda birbirlerine bağlanan çeşitli küçük üretim ve hizmet şirketleriyle iş birliği yapmaktadır. Fakat üretim ve dolaşım sürecinin dijitalleşmesi sonucu metalarda da değişiklik yaşanmaktadır.

\footnotetext{
3 Yakınsallık: Vygotsky’ın geliştirdiği Yakınsal Gelişim Alanı kuramından türemiştir. Kuram, gelişim psikolojisi ve eğitimle birlikte çocuklara yöneliktir. Kurama göre, bireyin tek başına problem çözme kabiliyetiyle, konunun uzmanlarıyla iş birliği yaparak, onların danışmanlığında problem çözme kabiliyeti ve gelişim seviyesi arasında var olan uzaklığı belirlemektedir (Kapanadze, 2019: 185). Buna göre her bir medya platformu da problem çözmede iş birliği kurarak, gelişim sağlamaktadır.
} 
Dijital yaşamda, her veri meta olarak değerlendirilmekte ve geliştirilmektedir. "Sembolik ürün ve hizmetler” (Schiller, 1991: 30) şeklindeki metalar, küreselleşen dünyanın parçası olmakta fakat diğer metalar gibi bir genellemeye dahil edilmeyecek kadar çeşitli niteliklere sahip olmaktadır. Şirketler açısından metalaştırma aşamalarında bazı faydalı imkânlar ortaya çıkarmaktadır. Metalardaki en önemli nitelik, bünyesinde gizli olan enformasyonel içerikler bulundurmasıdır. Metalar, gayri-maddidir, tükenmezler, bozulmazlar aksine depolanır, işlenebilir ve daima tekrar üretilme imkanını barındırmaktadır (Kıyan, 2015: 38).

Fakat bu metalar, diğer ürün ve hizmetler gibi tekrar satın alınabilir durumda değildir (Straw, 2000: 155). Örnek verilecek olursa; kitap veya bir bilgisayar oyunu bir defaya mahsus olarak alınmakta veya bir filme ikinci defa gidilmemekte bunlarda kullanım değeri, sürekli 'yenilik' ve 'farklılık' üzerine kurulu olmaktadır (Garnham, 1990:160). Bu nedenle metalar, devaml içerik ve biçim değişikliğine uğrayarak, tekrar ve tekrar metalaştırılmaktadır. Enformasyonel içerik üretimi ve tekrar üretim arasında maddi boyutta da farklılık bulunmaktadır. İlk kopya üretim çoğunlukla yüksek maliyet içermekte fakat ilk birim üretiminden sonra diğerlerinin marjinal maliyeti "ölçek ekonomisi” gereği giderek azalmakta neredeyse sıfırlanmaktadır (Doyle, 2002: 13, Garnham, 2000: 55).

Öte yandan bu metalar, mülkiyet hakimiyeti hayali şekilde yön değiştirmektedir. Sembolik nitelikte herhangi bir meta, piyasa koşullarında işleme dahil olduğunda standart bir meta değiştokuşunda olduğu gibi kullanım ve değiş-tokuş değerleri aksi yönde hareket etmemektedir. Örneğin, herhangi bir filme gidildiğinde, satın alınan durum filmin kendisi değildir, belli bir zaman diliminin satın alınmasıdır. Mülkiyet yine üreticinin kendinde kalmaktadır. Bu durumda meta (içerik olarak), tekrar üretilme gereksinimi olmadan değerlenme aşamasına dahil olmaktadır. Metaların gerçek kullanım değerlerinin yanı sıra ikincil bir değer yaratımı olarak, dünyayı anlamak ve anlamlandırmak üzerine etkileri de söz konusudur. Dolayısıyla metalar, dolaşımda oldukları aşamada ideolojik işlevini de yerine getirmektedir (Kıyan, 2015: 38).

Sembolik metalarsa, tüketim aşamasında yok olmamaktadır. Var olan bu nitelikleriyle, tüketimde diğer metalarla karşılaştırıldığında azalma yaratmadığından, kullanımda dışlayıcı bir özellik sergilemeyeceği kanısıyla kamusallık vasfı kazanmaktadır (Ryan, 1992: 75). Metalar tarafından sergilenen bu eylemlerle sermaye devresinde, özellikle üretilen içeriğin kâra dönüştüğü dolaşım sürecinde kısa devre yaratılmaktadır. Dijitalleşen içeriklerin internet ortamındaki hali de bu duruma uygunluk göstermektedir. Murdock (2011: 27-28), bu biçimdeki içerikleri dijital armağan (digital gifts) olarak tanımlamaktadır. 
Şirketlerin piyasada karşılaştığı ve çözüm yolu aradıkları bir başka sorun da metaların denetimsiz bir şekilde kullanıcılara sunulmasıdır. Bu soruna dair çözüm yolunu reklamcılık alanı geliştirmiştir. Reklamcılık, içeriklerin dolaylı yoldan metalaştırılmasının yolunu açmaktadır (Winseck, 2011: 30). Günümüz kapitalist sistem uygulamaları açısından bakıldığında geliştirilen çözüm yolları, içeriği denetimli hale getiren fikri mülkiyet hakları (patent, telif hakkı vb.) olarak görülmektedir. Fikri mülkiyet hakkı, enformasyon toplumu kuramlarında ifade edilen bolluk ekonomisi şeklinde iyimser yaklaşımlara, niçin eleştirel yaklaşılması gerektiğini açıklamaktadır.

Fikri mülkiyet hakkıyla ilişkili çözümün arkasında yatan ana unsur, serbest dolaşımın çevresine devlet veya hukuksal düzlemde bir ücret sınırı çekilerek, içeriğin serbest şekilde yayılmasını engellemek, dağılımını sınırlamak ve buna olan erişim halini denetlemek veya belirli kurallara tabi tutmaktır. Mülkiyet hakkı kavramında tekel oluşturmak amacıyla üreticiyi ve onun piyasada yer edinmesini sağlayan ara katmanları kapsayacak şekilde geniş setler kurulmaktadır (Landes, 2011: 100). Lewis Hyde (2008: 125), bu tür uygulamaları, 'fikirlere kilit vurmak' olarak belirtmektedir. Hukuk, denetim sağlamak adına temel araçlardan biri haline gelmiştir.

Sembolik metalarla ilgili bir başka nitelikte, ölçülebilir ve fiyatlandırılabilir olmasıdır. Enformasyon, sahip olduğu anlamdan bağımsız bir şekilde, Claude Shannon’un “Matematiksel İletişim Kuramı'yla" ölçülebilir bir hal almıştır (Çalışkan, 2009: 30). Enformasyon, taşıdığı anlamdan bağımsız halde incelendiğinde ise diğer metalarda olduğu gibi kullanım değeri bakımından eşdeğer biçimde oran (kilobyte, megabyte, gigabyte vs.) ölçüleri belirlenebilmektedir. Hizmet şekli olarak internet, son kullanıcıya en küçük birimin bile hesaplandığı bir ölçülebilirlik sağlamaktadır. Ancak sembolik metalar dahilindeki en önemli sorun, üretilmiş son birim çıktısının ölçülebilirliği ve bu ölçülebilirlik özelinde gerçekleşecek fiyatlandırmadır. Robert Babe'e göre (1995: 12), enformasyonların piyasada işlem görebilmesi, birim başına ücretin değerlendirilebilmesine imkân sağlayacak biçimde ölçülmesinin gerekli olduğuna vurgu yapmaktadır. Babe (1995: 31-32), enformasyonun korunduğu maddi veya fiziksel araçlarla ölçümlenmeye gidildiğini ifade etmektedir.

Ticari kuruluşlar, metaya değer katan içerikleri göz ardı ederek, içerikleri depolayan ya da depolama işlemine yardımcı olan altyapı, donanım ve nicel özelliklere (sayfa sayıları, kelime sayıları, bitler vs.) odaklanıp ücretlendirme işlemini gerçekleştirmektedir. Mosco (1988: 4-5), bilgi ve iletişim araçları aracılığıyla tüketiciye aktarılan içeriğin giderek yaygınlaştığı çağdaş toplumları, "ödemeli toplum” olarak nitelendirmektedir. 


\section{Sosyal Medyada Dijital Emek}

İnternet kullanıcıları, enformasyon ve iletişim teknolojilerini satın alan ve tüketen olarak hareket etmektedir. Kullanıcılar, mobil telefonlar, tabletler, masaüstü bilgisayarlar, laptoplar, işletim sistemleri, uygulama yazılımları ya da müzik, içerik, video, oyun gibi çevrimiçi erişimleri satın almakta ve kullanmaktadır. Bu roller içerisindeki kullanıcı, metalarla parayı değiş-tokuş eden tüketiciler olarak davranmaktadır. Bahsedilen değiş-tokuş vasıtasıyla sermaye, meta biçiminden para biçimine dönüşmektedir (Fuchs, 2015: 355).

Metada belirginleşmiş artı emek şeklinde bulunan potansiyel biçimden, enformasyon ve iletişim teknolojilerine sahip olmak ya da oluşturmak için tüketicinin ödediği paradaki eylemsel biçim halinde bir kâr gerçekleşmektedir (Marx, 2015: 1885).

Kullanıcılar, enformasyon ve iletişim teknolojilerinin işçisi konumunda değil, üretüketici konumunda yerini almaktadır. Kullanıcıların sermaye birikim sürecindeki rolü ise metalarla para değiş-tokuşu yaptıkları ve tüketim adına bir kullanım değeri edindikleri yeni meta ve daha fazla para aşamasında açığa çıkmaktadır. Tüketim aşamasında kullanıcılar, anlam inşa etme ve kültürel bir süreç yaratma eyleminde bulunmaktadır. Kullanıcılar, gündelik yaşamında bu tür ürünlerin kullanımında farklı meta anlamları yaratmaktadır. Örneğin; kullanıcılar tarafından yeni bir mobil oyunu; eğlendirici, sıkıcı, şiddet eğilimli, duygusal, kişiselleştirici ya da diğer oyuncularla sosyalleşmek adına iyi bulanabilir (Fuchs, 2019: 344). Kültürel ürünlerin kullanımı ve tüketim sürecinde kullanıcıların ürettikleri şeyler, anlam olarak değer görmektedir. Tüketici konumunda olan enformasyon ve iletişim teknolojisi kullanıcılarının bu rolleri, kullanıcıların internet üretüketimi veya tüketim çalışması olarak adlandırılmasına neden olmuştur.

Sosyal medya platformları, farklı kullanım amaçlarına odaklanmaktadır. Tüm platformlarda ortak olan özellik, kesinlikle 'sosyal' olmaları ve diğer internet kullanım şekillerinin (örneğin, e-mail göndermek ya da online haber okumak) sosyal olmaması değildir. Daha fazla sosyalleşmenin diğer iki hali olan enformasyon ve iletişimle birlikte ilerleyen paylaşma, topluluk ve kolektifliğe odaklanan sosyallik şeklini ifade etmektedir. Tüm bu platformların ortak özelliği, hedefli reklamcılık alanının kullanıcı verilerini (içerikler, sosyal ağlar, online eylemler) metaya çevirmeye dayanan bir iş modeli geliştirmesine imkan sağlamasıdır. Verilerin kullanıma açık olması, gözetim ve metalaşma olgusuna zemin hazırlaması adına şirketler, yasal olarak oluşturdukları kullanım şartları ve gizlilik politikalarını, platformlarda kullanıcılarının onayını bekler hale getirmiştir (Fuchs: 2015). 
Bir hesap açmanız, içerik oluşturmanız, paylaşmanız ve başkalarıyla mesajlaşmanız ya da iletişim kurmanız dahil olmak üzere, ürünlerimizi kullanmanız sırasında să̆ladı̆̆ınız içerikleri, mesajları ve diğer bilgileri toplamaktayız. Ayrıca sunduğumuz özellikler aracılı̆̆ıyla gördüğünüz şeyler de buna dahil olabilir. Tamamen size özel ve kişiselleştirilmiş ürünler oluşturmak amacıyla sizden ve başkalarından topladı̆̆ımı ve öğrendiğimiz veriler, ürünlerimizi kullanma ve ürünlerimizde etkileşim kurma biçiminiz; ürünlerimizde ve başka yerlerde bağlı olduğunuz ve ilgi duyduğunuz kişiler, yerler veya diğer şeyler doğrultusunda bağlantılarınız, tercihleriniz, ilgi alanlarınız ve hareketlerinize ilişkin bilgileri kullanıyoruz (Facebook, 2020).

Çoğu zaman kullanıcı, bu şartlara dikkat etmeden kişisel bilgilerinin sisteme aktarılmasını onaylamakta ve metalaşan verilere uygun kişiselleştirilmiş reklamlarla karşılaşmaktadır. Özetle metaları oluşturan üreticiler mevcuttur, aksi halde metalar var olamaz. İnternet platformlarındaki metalar kullanıcı verileriyse, bu verilerin oluşturulma aşaması da değer üreten emek olarak değerlendirilmektedir. Bu noktada dijital emek kavramı öne çıkmakta (Burston, Dyer-Witheford ve Hearn 2010; Scholz, 2013) ve Smythe'1n izleyici emeği tekrar canlanıp internet üretüketici-metası kavramına dönüşmektedir. Dijital emek sosyal medyada, internet platformları vasıtasıyla, reklamveren müşteriye ücret karşılığı satılan ve karşılığında kullanıcılara hedefli reklam olarak geri dönen internet kullanıcı-metası oluşturmaktadır (Fuchs, 2015: 357).

Enformasyon toplumunda pek çok birey için dijital medya, insanların kendi iletişim güçlerini kullanıma dahil etmeleri için önemli bir etkileşim aracı olarak konumlandırılmaktadır. $\mathrm{Bu}$ nedenle emek gücü kısmen de olsa, iletişim gücüyle eşdeğer görülmektedir. $O$ halde sosyal medya platformlarını iletişim aracı olarak kullanan kullanıcılar, dikkate değer miktarda anlamlı iletişim gerçekleştirmektedir. Aksi takdirde sosyal medya platformlarını kullanmayan bireylerin, yaşamları daha az anlamlı etkileşimler içermektedir. Platformların kullanıcılara bu sebeple uyguladığı baskı, onları fiziksel olarak yok eden bir baskı değildir, aksine kullanıcıyı tecrit ve toplumsal dezavantajlarla tehdit eden bir baskı türüdür. Buna bağlı olarak sosyal medya kullanıcısı, emeklerinden dolayı ücret almayan ücretsiz işçi olarak tanımlanmaktadır (Fuchs, 2019).

Köle çalışmasında da ücret mevcut değildir ve tüm iş gününün karşılığı ödenmediğinden, sömürü sınırsızlaştırılmaktadır. Gerekli emek zamanı en aza indirgenmekte, artı-değer üreten 
emek zamanı da en yükseğe çıkarılmaktadır. Dijital emeğin, klasik kölelikle ortak özelliği ise emeğin ücretsiz ve yüksek oranda sömürüye izin veriyor olmasıdır. Dijital işçinin de klasik köleliğinde emeği, meta olarak görülmemektedir. Her ikisi de emek piyasasında emek gücünü meta olarak satmamaktadır. En önemli fark da baskı biçimidir, köleler, köle sahibinin özel mülkü olarak varlığını sürdürmekte, dijital işçi ise özel mülk olarak yaşamına devam etmemektedir (Fuchs, 2015: 395).

Mies'e göre (1986: 110) de, sosyal medyada dijital emek, ev işini andırmaktadır, bunun nedeni ise ücretsiz ve emek olarak algılanmasının güç olmasıdır. Ev işi gibi 'normalde kapitalistlerce karşılanması gerekli olan maliyetlerin dışsallaştırılması ya da dış bölgelere aktarılması' durumunu içermektedir. 'Kitle kaynak kullanımı' söylemi, tam olarak da kapitalistlerin emek maliyetlerinden tasarruf etmesine yardım eden bu dış kaynak kullanım aşamasını açığa vurmaktadır. Ev işi gibi, dijital emek de 'kontrolsüz, sınırsız bir sömürü kaynağı'dır (Mies, 1986: 16).

\section{Ticari Medya Platformu: Google}

Larry Page ve Sergey Brin tarafindan 1998 yılında kurulan Google, 19 Ağustos 2004'te halka açık bir şirket haline gelmiş (Vise ve Malseed, 2005: 4) ve arama motoru olarak kullanıcılara sunulmuştur. Arama motorunda, PageRank olarak isimlendirilen, birçok bağlantının kullanıcı aramasıyla hedeflenen sonuca ulaşmasını sağlayan ve arama sonuçlarını sıralayan, bir algoritma kullanılmaktadır. Algoritma www'da gezen otomatik yazılım ajanları tarafından kullanılmakta, belirli web sitelerine ulaşan bağlantıları saymakta ve sonuçları analiz etmektedir (Fuchs, 2016: 174).

$\mathrm{Bu}$ süreçte Google, aramayı araştırırken, -Page'in "bilgisayar bilimi ve metafizik arasındaki kesişme" olarak isimlendirdiği- felsefe ve sinirbilim alanlarını incelemekte ve arama dünyasının sistemini ima edip, David Gelernter'ın (1993: 92), var olan dünyanın gerçek bir modelini geliştirdiği gibi, gerçek dünyanın dijital yansımasını dikkate alarak, arama işlemini gerçekleştirmeyi planlamaktadır. Google aramaları, aramayı birçok kullanıcı için kişiselleştiren ve kolay kullanım sağlayan bir kullanıcı ara yüzü geliştirerek, işlemine devam etmek adına geliştirilmektedir (Fuchs, 2016: 174).

Bir bilgisayarla arama yapmak için ise temelde sistemin dijital forma dönüştürülmesi gerekir, bu durumda da bitler ve baytlar devreye girmektedir. Page ve Brin, Google dünyasını; simulakr, (bir gerçeklik olarak algılanmak istenen görünüm), world wide web'i okunabilir bir dijital 
dosya, erişilebilir bir bilginin 'sermayesi' ve veri tabanı olarak geliştirmek için çalışmalar yürütmektedir (Gilder, 2019: 37). Google, dünyada mevcut olan kitapların tamamına yakınını dijitalleştirmektedir; dünya dillerini ve çevirileri, gezegenin topografyasını (Google Maps ve Google Earth), bireysel sokaklardaki (StreetView) yüzeyleri, yapıları ve sokaklarda mevcut olan trafiği...

Gerçekte Google, geleneksel şirket politikaları doğrultusunda işleyen bir kurum değildir. Bütün içeriğin ve bilgilerin ücretsiz olmasını sağlamak adına "bilgi özgür olmak ister" sloganıyla hareket etmektedir. Google, nakit ve kredi için ürün ve hizmet sağlamaya uğraşmamakta, kullanıcılara; ücretsiz bilgi, sanat, kültür ve aydınlanma sağlamaktadır. Bu sebeple Google'ın ticari arenadaki başarısı esrarengiz görünmektedir. Buna bağlı olarak Google'ın ticari teknik planının nasıl ilerlediğine dair bilgiler sunmak yerinde olacaktır. Bunun içinde Google reklam modellerini incelemek gerekmektedir.

Google'1 diğer ticari platformlardan ayıran en önemli özellik, mevcut uygulamalara yüklediği bütün engelleri yok sayan ve dünya sistemi adına yeni bir ekonomik faaliyet alanı yaratan 'arama motoru reklam modellerini' geliştiriyor olmasıdır. Reklam faaliyetleri ise Google AdWords (Google Ads) ve Google AdSense uygulamalarıyla gerçekleşmektedir. Google platformunda yer alan arama motoru reklam modeli, 2000 yılinda Google AdWords uygulamasıyla başlamıştır. 2019'da Google AdWords ismi Google Ads olarak değiştirilmiştir. Google Ads, arama motoru özelinde anahtar kelimeler hedefleme stratejisiyle işlemini sağlamaktadır. Ücretlendirme sistemiyse, “Tıklama Başına Maliyet” modeliyle gerçekleşmektedir (Google, 2020).

Google Ads'le büyük bütçeler harcamadan reklam yapmak ve harcanan bütçe neticesinde sahip olunan bilgileri, sunulmakta olan hizmetlere göre araştırmak ve ölçümlemek mümkün hale gelmektedir. Google Ads reklamlarında, çok açık ve spesifik hedeflemeler gerçekleştirilerek reklam yayını yapılmaktadır. Google Ads, arama ağı ve görüntülü reklam ağı modeli olmak üzere iki temelde oluşturulmaktadır. Arama ağı reklamlarında, Google Ads paneli üzerinden anahtar kelime grupları belirlenir. Anahtar kelime grupları dahilinde dijital reklam kampanyaları oluşturulmakta ve kampanyaların potansiyel tüketicilere ulaşması hedeflenmektedir. Hedefleme özelliklerine bağlı olarak ulaşılması istenen internet kullanıcılarının, Google'da arama yaptıkları esnada karşılarına arama ağı reklamları getirilir ve buna bağlı olarak tüketiciyle işletme arasında etkileşim sağlanması beklenmektedir. Öte yandan 
hedeflenen anahtar kelimeler dahilinde reklam kampanyalarının arama sayfalarının en başında yer alması adına eylemlerde bulunulur ve tüketicinin aksiyona geçmesi beklenir (Google 2020).

Arama ağı reklam modelinin en önemli hedefi, reklamverenler tarafindan hedeflenmek istenen kullanıcıların, reklamları tıklamaları ya da telefonla arama eylemlerini gerçekleştirmesidir. Arama ağı reklamları internet ağında aktif şekilde veri arayışını gerçekleştiren kullanıcıları hedeflemekte ve buna bağlı olarak kullanıcıyla ilişkili reklamların gösterilmesini sağlamaktadır. Ayrıca arama ağında yayınlanmakta olan reklamın gösterimi için reklamverenlerden ücret talep edilmemektedir. Reklamverenler, sadece kullanıcıların reklama tıklamasıyla açık arttırma sistemine bağlı olarak belirlenen kurallar dahilinde ücretlendirilmektedirler (Berki, 2019: 145).

Görüntülü reklam ağı da reklamverenin doğru hedef kitleyi bulması için tasarlanmıştır. Hedefleme yöntemiyle mesajlar, stratejik olarak doğru yer ve zamanda potansiyel müşterilere ulaşmaktadır. Ayrıca kitleler yardımıyla yeni tüketicilere ulaşmak ve mevcut tüketicilerle etkileşim kurulmaktadır. Benzer kitle ve pazarda bulunan kitleler yardımıyla ürünlerle ilgilenme olasılığı yüksek tüketiciler hedeflenmekte ve bu sayede yeni potansiyel müşterilere ulaşmak mümkün hale gelmektedir. Siteyi ziyaret eden kullanıcılarla tekrar etkileşim sağlamak adına yeniden pazarlama listeleri verilerinden yararlanmak da mümkündür. Ayrıca Google Ads, zamanla otomatik optimizasyon gerçekleştirerek, hangi kitlelerin reklamverenlerin işine yaracağını belirlemektedir. Otomatik teklif özelliğiyle reklamverenlerin yatırım getirisi sağlamaları için teklifler otomatik olarak ayarlanabilir. Akı1lı görüntülü reklam kampanyalarıyla, Google Ads'deki dönüşümler geliştirilerek, otomatik hedefleme ve teklif verme nitelikleri en iyi şekliyle reklam öğelerinin bir araya gelmesini sağlamaktadır (Google, 2020).

Sonuç olarak arama ağı reklamı, belirli ürün ya da hizmetleri arayan kullanıcılara ulaşmaktadır. Görüntülü reklam ağı ise satın alma eyleminin ilk aşamasında kullanıcıların dikkatini çekmeye odaklanmaktadır. Reklamlar, ürün ya da hizmeti kullanıcı aramadan sunulmaktadır. Siteyi ya da uygulamayı daha önce ziyaret eden kullanıcılar hedeflenerek, yeniden pazarlama kampanyası oluşturulabilir ve kullanıcılara geçmişte ilgilenmiş oldukları ürün veya hizmet hatırlatılabilir (Google, 2020).

Yeniden pazarlama kampanyaları, web siteleri ya da mobil uygulamalarla önceden etkileşim gerçekleştiren kullanıcılara erişim sağlama alanı olarak kullanılmaktadır (Google, 2020). 
eniden pazarlama kampanyaları yoluyla işletmeler, web sitelerini ziyaret eden, alışveriş aşamasında ödeme noktasına kadar erişim sağlayan fakat satın alma eylemini gerçekleştirmeyen ya da daha önce alışverişi gerçekleştiren ve benzeri farklı özelliklerdeki kullanıcıları hedeflemeye imkan tanıyan reklamları içermektedir (Berki, 2019:147). Buna bağlı olarak işletmelerin web sitelerini ziyaret etmiş kullanıcılara, ziyaret ettikleri sayfalar aracılığıyla kişiselleştirilmiş reklam yayınları sağlamak mümkün hale gelmiştir.

Alışveriş reklamlarına bakıldığında, kullanıcıların Google arama ağında gerçekleştirdikleri arama sorgulamalarıyla işletmelerin satışını gerçekleştirdiği ürünlerin eşleşmesi sonucu ürün ya da hizmetin ismi, resmi, başlığı, fiyatı kullanıcıya sunulması söz konusudur. Reklamverenler, ürünlerinin alışveriş reklamlarında gösterilmesi için ürün ve bilgilerini Google Merchant Center"'a yüklemektedir (Alçelik, 2017: 109). Bu uygulamayla işletmelerin web sitesinde bulunan ve reklamı gerçekleştirilmek istenen ürünleriyle ilişkili içerikleri, reklamlarda kullanılmaktadır.

Youtube'da yayınlanmakta olan video reklamlarının, kurgusu ve takibi Google Ads aracılığıyla yapılmaktadır. Tasarlanan reklam videoları Youtube'da yayınlandığı gibi Google reklamlarını yayınlamak isteyen web sayfalarında ve mobil uygulamalarda yer edinmektedir (Google, 2020). mail reklamları ise Google Ads ara yüzü kullanılarak Gmail için özel hazırlanmaktadır. Reklamlar, mail sisteminin ana sayfasında bulunmakta ve kullanıcı sekmeyi tıklandığında bir mail gibi açılan reklam içeriğiyle karşılaşmaktadır. Bu reklamlar, maillerde bulunan anahtar kelimelere göre sınıflandırılmakta ve kullanıcıya da bu segmentasyona göre sunulmaktadır (Google, 2020).

Google, dünyanın bu tür reklam modellerini gereksinim olarak benimsemesini sağlamaya çalışmaktadır. Brin ve Page, arama ağı modeli dahilinde oluşturulan verileri tam olarak görüntüleyen reklamların, hangi reklamı memnuniyetle karşılayacağını belirleyebilmek için gerekli olan bilgilerin internet ağında var olduğunu varsaymakta ve arama sonucundan kullanıcıların 'görmek' istediği reklamı üretebilme çalışmaları yürütmektedir (Gilder, 2019: 40.

Levy (2011), Google'da reklamın, yayıncı ile reklamveren arasında iki yönlü ilerlemesini değil, kullanıcının da dahil olacağı üç yönlü bir işlem yaratılması gerektiğini savunmaktadır. Fakat Google, pratikte "kullanıcıya odaklan gerisi gelir" ilkesini uygulayarak, kullanıcıya tek yönlü

\footnotetext{
${ }^{4}$ Google Merchant Center: Alışveriş reklamlarında şirket ve ürün bilgilerinin Google’a sunularak, Google yoluyla alışveriş yapan kullanıcılara, ürünlerin ulaşmasını sağlayan bir uygulamadır. Bu yolla tüketiciler, satılan ürünlerle ilgili Google platformlarında arama yaptıklarında, şirket ve ürünlerle ilgili bilgi almaktadır (Google, t.y.).
} 
bir alan sunmaktadır. Google bu hedefe ulaşmak adına reklamları, sponsorlu bağlantılar olarak tanımlamakta ve sadece tıklamayla ölçümlenen başvurular için ücretlendirme eylemini benimsemektedir. Reklamverenlerin de yeterli tıklanma oranlarına sahip olmadığı reklamlarını kaldırarak, reklamlarını revize etmesi istenmektedir.

Ayrıca Google, Google Analytics uygulamasıyla web sitesi sahiplerine ve web yöneticilerine ücretsiz web sitesi analiz platformu sunmaktadır. Bu platformla, izleme kodu yüklü olan bütün web siteleri adına oturumlar, kullanıcı davranışları, hedef kitlenin lokasyon cihazları ve eticaret eylem verilerinin ölçülmesi mümkündür. Analytics sayesinde web uygulayıcıları, web sitesindeki ziyaretçi etkinliklerini anlamaya yönelik veriler elde eder ve bu etkinliklere özel hedef oluşturarak kullanıcılara mesajlar sunmaktadır (Magna Dijital, t.y.). Bu doğrultuda web sitesi uygulayıcıları, Google reklamlarından birini seçerek etkinliklerini gerçekleştirebilir ve mesajını doğru kanalla vererek kullanıcıyı aktif hale getirebilmektedir.

Ayrıca Google kurucuları, reklama dair gelişmeleri kurumsallaştırırken genel felsefelerini on maddede sıralamaktadır. Ancak bu maddeleri alt mesajlarını okuyarak ifade etmek Google'ın gerçek hedeflerini gösterecektir (Cleland ve Brodsky, 2011).

1. Kullanıcı odaklı uygulamalar bulun, devamı gelecektir. -Google'ın kullanıcıya sunduğu 'hediyeler', ücretsiz kişisel bilgilerin sisteme yüklenmesini gerektirmekte, Big Data'da verilerin yer almasını sağlamaktadır.-

2. Tek bir şeye odaklanmak, en iyi olandır. -bilgi pazarına hükmedebilmek için yapay zekanın geliştirdiği 'arama ve sıralama' işinde en iyisi olmalısınız. Alanınızda bulunan her şey ve herkesle ilgili -kişisel bilgiler de dahil- bilgi sahibi olmalısınız.-

3. Hızlı olmak, yavaş olmaktan iyidir. -hızlı olmak, dikkatli olmaktan ve hatasız ilerlemekten daha iyidir.-

4. İnternet dünyasında demokrasi işlemektedir. -Google, zeka ve kanıtlara dayalı, üstün özellikleri olduğu düşünülen kişiler tarafından yönetilen bir yönetim biçimine sahiptir.-

5. Bir cevaba ihtiyacınız olması için masanızda bulunmanıza gerek yoktur. -Mobil reklamların varlığı, kullanıcıları her alanda bulma özelliğine sahiptir.-

6. Kötülük yapmayarak da para kazanabilirsiniz. -hızlı ve özgür olan birçok şey günaha sebep oluyorsa, Google, veri merkezini, rüzgar değirmenleri ve güneş uzantısı vasıtasıyla net-sıfır karbon ayak iziyle çalıştırmasıyla gurur duymaktadır.-

7. Her zaman daha fazla bilgi mevcuttur.

8. Bilgi gereksinimi tüm sınırları aşmaktadır. -kullanıcılar dünya vatandaşıdır, Google Translate de kullanıcılara dünya çapında bir sınır çizmektedir.- 
9. Takım elbiseniz olmasa da ciddi bir profil oluşturabilirsiniz.

10. 'Harika' yeterince iyi görünmemektedir. -Kullanıcılar, sıradan harikalardır.-

Google işlemlerini, kullanıcıların hayatlarına dahil olarak, sisteme aktardıkları kişisel bilgilerin kullanımı sonucu gerçekleştirmektedir. Kullanıcıların farkında olmadan emek sarf etmesi, bu işleyişin devamını sağlamaktadır. Bu sebeple Google'ın sermaye birikim stratejisini incelemek yerinde olacaktır.

\section{Google'ın Sermaye Birikimi}

Google'ın sermaye birikim sürecine göre, kurum maddi yatırımını teknolojiye ve iş gücüne (ödemesi yapılan Google çalışanları) yapmaktadır. Google çalışanları, Google hizmetlerinin üretimi adına değişmeyen sermaye birikimini kullanmaktadır. Ayrıca Google hizmetleri meta olarak kabul görmemekte ve kullanıcılara ücret dahilinde sunulmamaktadır. Ücret talep etmeden kullanıcılara birçok alanda hizmet sağlayan, arama ve erişimi kolaylaştıran Google, kullanıcı aramalarına bağlı olarak verileri depolamaktadır. Google arama motoru, Google'a bağlı olarak indekslenen web sitesi sayfaları ve site içeriklerini oluşturan, bütün bu ücretsiz iş gücüyle kuvvetlendirilmektedir (Fuchs, 2018: 75).

Ancak Google maddi kazanç elde etmek için kullanıcı verilerini kullansa bile kullanıcılara bu konuda ücret ödememektedir. Google hizmetleri ve internet içerik üreticilerinin ücretsiz iş güçleri de bu bağlamda Google'ın sömürü aracı, olarak düşünülmektedir. Kullanıcılar, farklı şekilde iş gücünde bulunmaktadır. Google'da anahtar kelimeyle arama yapmak, Gmail yoluyla mail aktarmak, Youtube aracılığıyla bir video arayışında bulunmak veya yükleme yapmak, Google Maps veya Google Earths yoluyla lokasyon aramak (Fuchs, 2018: 73), Google uygulamalarında gerçekleşen tüm arama ve yükleme eylemleri gerçekleştirmek gibi aktiviteler, kullanıcı arama verilerine erişimi ve kullanıcı verilerini elde ederek yeni içeriklerin üretimini sağlamayı kolaylaştırmaktadır.

Buna bağlı olarak, yeni metalar elde edilmekte ve internet üreten tüketici metalarına erişim sağlanmaktadır. Google uygulamaları ve internet içeriği üreticilerinin ücretsiz iş gücü kullanıcıların ilgi alanlarıyla ve aktiviteleriyle ilişkili birçok veriden oluşmaktadır. Kullanıcıların gerçekleştirdiği bu işler Google'ın bedava sermaye elde etmesini sağlamaktadır. Elde edilen üreten tüketici metası ise reklamverenlere satılmaktadır. Google reklamverenlerin maddi kazancını şu şekilde sağlamaktadır: Reklamverenler, hedef reklamlarını Google kullanıcılarına sunmak için, üreten tüketici metalarının verisini Google'dan satın almaya yönelik eylemlerde bulunmaktadır. Fakat Google'ın meta olarak sattığı şey Google hizmetleri değildir, kullanıcılar ve onların verileridir (Fuchs, 2018: 72). 
Google tarafından kullanılan çalışma zamanı, hem ücretli çalışanların zamanını hem de kullanıcılar tarafından Google hizmetlerinde çevrimiçi olarak geçirilen zamanın tümünü içermektedir. Söz edilen ilk çalışanın ücreti ödenirken ikinci çalışanın ücreti ödenmemektedir (Fuchs, 2018: 73). Buradaki bilgi bu nedenle bedava üretilmektedir. Ücreti ödenmeyen çalışandan edinilen veriler, Google'ın reklam uygulamalarını tasarlaması adına reklamverenlere satılmakta ve tekrar bu veriler ücretsiz çalışan kullanıcıya sunularak, satın alma eyleminde bulunmaları için beklenmektedir.

Öte yandan Google sermaye birikimi sağladıktan sonra kullanıcının gözetimiyle ${ }^{5}$ ilgilenir ve bu nedenle Google gözetimi bir ekonomik gözetim biçimi olarak tanımlanmaktadır. Google'ın kullanıcıların ekonomik gözetimi adına yasal dayanağıysa, kendi hizmet ve gizlilik politikalarıdır (Fuchs, 2018: 73).

Google'ın genel hizmet politikaları ve çalışma şekline bakıldığında, reklamların, Google ürünlerinin finanse edilmesine yardım ettiği, ürünlerin herkese sunulabilmesini sağladığı ve gelirin büyük bir kısmının reklamlardan elde edildiği (Google, t.y.) ifadesi görülmektedir.

Kullanıcıların bu sürece katkısı da şu şekilde açıklanmaktadır: "Kişisel verilerinizi, ürünlerimizi sizin için yararlı bir hale getirmek için kullanmaktayız. Bu veriler aracılığıyla aramalarınızı otomatik olarak tamamlamaktayız. Harita uygulamasıyla evinize daha hızlı gitmenizi sağlıyoruz ve ilgi alanlarınıza bağlı olarak size daha fazla yarar sağlayacak reklamlar gösteriyoruz. Fakat kişisel verilerinizi kimseye satmamaktayız. Ürünlerin pek çoğunu oturum açmadan ya da kişisel bilgilerinizi kaydetmeden de kullanabilmektesiniz” (Google, t.y.). Ayrıca Google reklamcılığının nasıl ilerlediğine dair Google'da şu bilgilere yer verilmektedir "Büyük ve küçük, global ve yerel fark etmeksizin bütün işletmelere reklam alanı satıp para kazanıldığı, bu kazancında iki yöntemle elde edildiği belirtilmektedir. Bunlardan ilki, reklamveren işletmelerin, arama harita ve Youtube gibi çeşitli Google ürünlerinde reklam gösterip potansiyel müşterilere ulaşma olasılığı, ikincisi ise reklamveren işletmelerin, haber yayınları, bloglar gibi iş ortaklarının site ve uygulamalarında reklam alanı satın almalarıdır. Paranın büyük bir kısmı iş ortağına gitmekte ve içeriğinin finans desteği sağlanmaktadır. Reklamlar sadece Google’a ait

\footnotetext{
${ }^{5}$ Gözetleme ve gözetim kavramı, hakkında veri toplananları etkileme veya devam etmesini sağlamak maksadıyla açıklanmış veya açıklanmamış herhangi bir kişisel veri depolanması ve izlenmesidir (Lyon, 2006: 12-13).
} 
değildir, pek çok internet sitesi ve içerik üreticilerinin de desteklenmesine katkı sağlamaktadır” (Google, 2020).

Google reklamcılığına dair gizlilik politikası da genel olarak şu şekildedir: "Google'a reklam verildiğinde reklamverenler bu platforma reklamlarını yerleştirmeleri için veya reklamların performansı (reklam tıklanma sayısı) adına ödeme yapmaktadır. Reklamverenler Google'a kişisel bilgilerinizi satın almak için ödeme yapmamaktadır. İstenmeyen hiçbir veri reklamverenlerle paylaşmamaktadır. Reklam performanslarını anlamaları adına reklamverenlere rapor paylaşılmaktadır fakat bu, kullanıcının kişisel bilgileri açıklanmadan yapılmaktadır. Reklamlar kişisel veriler korunarak gösterilmektedir. Kullanıcını gösterilmesini istemediği reklamlar ve kişiselleştirilmiş reklamlar engellenebilmektedir" (Google, 2020). Google için kullanıcı verilerinin değeri, gerçekten paha biçilemez niteliğe sahiptir. Kullanıcı yararına elde edilen veriler, yine kullanıcı yararına reklama dönüştürülmekte ve kullanıcının satın alma eylemi için kullanılmaktadır. Gizlilik politikaları kullanıcıyı korumaya yönelik gibi görünse de reklamverenlere yalnızca kişisel verilerin verilmeyeceği adına vaatlerde bulunulmaktadır. Her ne kadar Google'ın genel politikasında kişisel verilerin korunmasına dair önlemler yer alsa da Google'ın reklamlar ve veriler anlayışında yer alan mottolar gerçeği göstermektedir:

Verilerinizi, reklamlar sizinle daha alakalı ve size daha faydal hale getirmekiçin kullanmaktayı, reklam yerleştirme karşılığında reklamverenlerden ödeme almaktayı, reklamverenlere kampanyalarının performanslarını göstermekteyiz (Google, t.y.).

Google, kullanıcı yararına kullanıcıların verilerini kullanıp uygulamalar gerçekleştirmekte ve kullanıcı verilerini metalaştırılarak sözde yalnızca yer satın alan ya da reklam yerleştirmeyi gerçekleştiren reklamverenlere, satmaktadır. Reklam yayınladıktan sonra ise kullanıcıların reklamlara nasıl tepki verdiği takip edilerek, yeni reklam stratejileri geliştirilmektedir.

\section{Kişisel Verilerin Korunmasında Uluslararası ve Ulusal Düzenlemeler}

İletişim teknolojilerinin gelişmesine bağlı olarak kullanıcılar, bilgiye ulaşırken kişisel bilgi aktarımında da bulunmaktadır. Kişisel verilerin aktarımı sağlanırken de belirli otomatik depolama yazılımları işlevini sürdürmeye devam etmektedir. Kişisel veriler depolanmakta, aktarılmakta ve belirli ticari medya platformları tarafından kullanıcı bilgileri başka yapılanmalara meta olarak satılmaktadır. Metalaşan veriler ise dijital emeğin parçası konumunda yer almaktadır. Dijital emek bireylerin internet ortamında aktardıkları verilere bağlı 
olarak gelişirken, bir problem olarak ise kişisel verilerin dolaşımında yaşanan kural ihlallerini beraberinde getirmektedir. Buna bağlı olarak uluslararası düzlemde veri korumayla ilgili düzenlemeler yapılmakta, birçok ülkede veri koruma yasaları hazırlayarak kişisel verilerin korunması konusunda düzenlemelerin ve denetlemelerin gerçekleşmesi adına eylemlerde bulunmaktadır (Kutlu ve Kahraman, 2017: 47).

Kişisel verilerin korunmasına dair eylemler uluslararası düzlemde incelendiğinde, Avrupa Birliğinde kişisel verilerin korunmasına ilişkin 1990’lı yıllarda başlayan çalışmalar sonucunda 1995 y1lında “Avrupa Parlamentosu ve Avrupa Konseyi Kişisel Verilerin İşlenmesi ve Serbest Dolaşımı Bakımından Bireylerin Korunmasına İlişkin Direktif”in kabul edildiği görülmektedir. Direktifin temel amacı ise Avrupa Birliği'ne üye olan ülkelerde kişisel verilerin korunmasına ilişkin düzenlemelerin uyumlaştırılma sürecini sağlamaktır.

$\mathrm{AB}$ üyesi ülkeler, kişisel verilerin korunmasına ilişkin kanuni düzenlemelerini bu Direktifi temel alarak gerçekleştirmektedir. Ayrıca Avrupa Birliği 95/46 sayılı Direktifi esas alarak sektörel bazlı düzenlemelerde bulunmaktadır. Bu düzenlemelerden en önemlisi, 2002/58/EC sayılı "Elektronik Haberleşme Sektöründe Kişisel Verilerin İşlenmesi ve Özel Hayatın Gizliliğinin Korunmasına İlişkin Direktif’tir. Avrupa Birliği, kişisel verilerin korunması alanında ortaya çıkan ihtiyaçları karşılamak üzere 2012 yılında yeni bir tüzük çalışması başlatmıştır. Ayrıca kişisel verilerin korunmasına ilişkin uluslararası düzeyde, OECD’nin “Özel Yaşamın Korunması ve Kişisel Verilerin Sınır Ötesi Akışına İlişkin Rehber İlkeleri” (23 Eylül 1980) ve Birleşmiş Milletler' in "Bilgisayarla İşlenen Kişisel Veri Dosyalarına İlişsin Rehber İlkeleri” (14 Aralık 1990) bulunmaktadır.

2010 y1lında 5982 sayılı Kanun'la yapılan Anayasa değişikliği ile Anayasa'nın 20. maddesine ilave bir fikra eklenmiştir. Söz konusu fikrada; "Herkes, kendisiyle ilgili kişisel verilerin korunmasını isteme hakkına sahiptir. Bu hak; kişinin kendisiyle ilgili kişisel veriler hakkında bilgilendirilme, bu verilere erişme, bunların düzeltilmesini veya silinmesini talep etme ve amaçları doğrultusunda kullanılıp kullanılmadığını öğrenmeyi de kapsamaktadır. Kişisel veriler, ancak kanunda öngörülen hallerde veya kişinin açık rızasıyla işlenebilir. Kişisel verilerin korunmasına ilişkin esas ve usuller kanunla düzenlenir.” hükmüne yer verilmiştir (Kişisel verileri koruma kurumu, 2018).

Ulusal düzlemde incelendiğinde ise 1982 Anayasasının ikinci kısmında, kişinin temel hak ve ödevleri düzenlenmektedir. Özel hayatın gizliliği de kişinin temel haklarından biri 
olarak kabul edilmektedir. Bu hak, Anayasa'nın 20. maddesinde güvence altına alınmıştır. Teknolojik gelişmelerin temel hak ve hürriyetlere müdahale edebilmeyi kolay hale getirmiş olması ve bu durumun hukuki bir sorun olarak kendini göstermesi bu konuda yasal düzenlemeler yapmayı gerekli kılmıştır.

2010 yılında 5982 sayılı Kanun'la yapılan Anayasa değişikliği ile Anayasa'nın 20. maddesine ilave bir fikra eklenmiştir. Söz konusu fikrada; "Herkes, kendisiyle ilgili kişisel verilerin korunmasını isteme hakkına sahiptir. Bu hak; kişinin kendisiyle ilgili kişisel veriler hakkında bilgilendirilme, bu verilere erişme, bunların düzeltilmesini veya silinmesini talep etme ve amaçları doğrultusunda kullanılıp kullanılmadığını öğrenmeyi de kapsar. Kişisel veriler, ancak kanunda öngörülen hallerde veya kişinin açık rızasıyla işlenebilir. Kişisel verilerin korunmasına ilişsin esas ve usuller kanunla düzenlenir." hükmüne yer verilmiştir.

Anayasada yer alan bu düzenlemeyle:

- Herkesin, kendisiyle ilgili kişisel verilerin korunmasını isteme hakkına sahip olduğu,

- Bu hakkın; kişinin kendisiyle ilgili kişisel veriler hakkında bilgilendirilme, bu verilere erişme, bunların düzeltilmesini veya silinmesini talep etme ve amaçları doğrultusunda kullanılıp kullanılmadığını öğrenmeyi de kapsadığı,

- Kişisel verilerin, ancak kanunda öngörülen hallerde veya kişinin açık rızasıyla işlenebileceği hükme bağlanmıştır.

Anayasada da, kişisel verilerin korunmasıyla ilgili detaylı düzenlemelerin kanunla yapılacağı belirtilmektedir. Bu kapsamda 26 Aralık 2014 tarihinde "Kişisel Verilerin Korunması Kanunu Tasarısı” TBMM Başkanlığına sunulmuştur. Tasarı, 24 Mart 2016 tarihinde kanunlaşmış ve 6698 sayılı Kişisel Verilerin Korunması Kanunu 7 Nisan 2016 tarih ve 29677 sayılı Resmi Gazete'de yayımlanarak yürürlüğe girmiştir.

5237 say1lı Türk Ceza Kanununun 135. maddesinde, kişisel verilerin kaydedilmesi, 136. Maddesinde, verileri hukuka aykırı olarak verme veya ele geçirme, 138. maddesinde, verileri yok etmeme fiilleri suç olarak düzenlenmiştir. Ayrıca Kanunun 140. maddesinde bu suçlarla ilgili olarak tüzel kişiler hakkında güvenlik tedbiri uygulanacağı hüküm altına alınmıştır (Kişisel Verileri Koruma Kurumu, 2018). 


\section{Sonuç}

Dijital emek, enformasyon ve iletişim teknolojileri alanında sermaye birikiminde gerekli olan, karşılığı ödenmemiş kullanıcı emeğinin ve emeğin diğer şekillerinin analizine odaklanmaktadır. Bu nedenle dijital emek, emek ve sermaye arasındaki ilişkiyi mevcut kapitalist üretim biçimi arklılıkları kapsamında değerlendirmektedir. Dijital emeğe bağlanan sermaye biçimleri, yeni iletişim teknolojilerinin gelişimiyle birlikte internet tabanlı üretim araçlarına odaklanarak hareket etmektedir. İnternetin gelişimi ve yaygınlaşmasıyla birlikte de tüketicilerin işe yönelme eğilimi, ağ tabanlı erişim alanına doğru genişlemektedir. Sosyal medya ve arama motoru kullanıcıları tarafından oluşturulan içerikler, tüketilirken üretilen davranışların izlerini taşıyan uygulamalar olarak analiz edilmektedir.

Sosyal medya ve arama motoru kullanıcılarının bu platformlarda gerçekleştirdikleri eylemler, satın alma özelliği taşıyan bilgiler ve anlamlar haline gelmektedir. Bu bilgiler ve anlamlarsa, reklamverenler nezdinde önemli görülmekte ve meta olarak değer görmeye başlamaktadır. Kullanıcıların oluşturduğu metalar, kâr sağlamak amacıyla ticari medya platformları tarafından işlenmektedir. Süreç içerisinde ve katılma durumlarına bağlı olarak üretilen metanın paraya dönüşmesi neticesinde, ticari medya platformlarına sahip olan şirketlerle platform kullanıcıları arasında sömürü ilişki oluşmaktadır. Sömürü ilişkisinin mevcut olduğu bu emek türü ise dijital emek, -karşılığı ödenmeyen emek- olarak adlandırılmaktadır.

Bu bağlamda araştırmanın örneklemi olan Google maddi kazanç elde etmek için kullanıcı verilerini kullanmakta ve kullanıcılara bu konuda ücret ödememektedir. Bu nedenle Google hizmetleri ve internet içerik üreticilerinin ücretsiz iş güçleri, Google'ın sömürü aracı olarak düşünülmektedir. Ücreti ödenmeyen kullanıcının oluşturduğu içerikler de, Google'ın anahtar sözcüklerle arama gerçekleştirmesi sonucu oluşturulan reklam uygulamaları da, kullanıcı verilerine dayanmaktadır. Google için kullanıcı verilerinin değeri, gerçekten paha biçilemez niteliğe sahiptir. Google reklam ve veri politikasında, verilerin kullanıcıyla bağlantılı ve kullanıcıya fayda sağlayacak reklamlarla karşılaşması için kullanıldığını, reklam yerleştirme karşılığında reklamverenlerden ödeme alındığını savunmaktadır. Bu bağlamda kullanıcı verilerinin satılmadığı ama kullanıcı verilerine uygun reklam alanlarının satıldığını açıklamaya çalışan bir politika olarak yerini almaktadır.

Kullanıcı yararına elde edilen veriler, yine kullanıcı yararına reklama dönüştürülmekte ve kullanıcının satın alma eylemi için kullanılmaktadır. Gizlilik politikaları kullanıcıyı korumaya 
yönelik gibi görünse de reklamverenlere yalnızca kişisel verilerin verilmeyeceği adına vaatlerde bulunulmaktadır. Kullanıcıların arama ya da içerik verilerinin meta olarak reklamverenlerle paylaşılıp paylaşılmayacağına dair vaatlere yer verilmemektedir. Sonuç olarak kullanıcı verilerini meta haline dönüştürerek, reklam stratejilerini bu doğrultuda yöneten Google, dijital emek kavramı örnek olmaktadır. Kullanıcıların kişisel verilerini belirlediği şartlar ve koşullara onay alarak kullanmaktadır. Buna bağlı olarak da belirlediği reklam yazılımlarıyla kullanıcının ilgisine uygun mesajları sunarak, üreten kullanıcıyı aynı zamanda tüketici konumuna getirmektedir.

\section{Kaynakça}

Adakl1, Gülseren (2014), “Türkiye'de Sermaye ve Sermayedarlar: Medya Sermayesi ve UltraÇapraz Bütünleşme”, Perspective, 8, ss.18-23.

Alçelik, Aykut (2017), Google AdWords, Dikeyeksen Yayıncılık, İstanbul.

Arthur, Christopher (1998), The Fluidity of Capital and the Logic of the Consept, (Editörler), Christopher Arthur ve Geert Reuten. The Circulation of Capital: Essays on Volume Two of Marx's Capital, London: MacMilan. p. 95-128.

Babe, Robert (1995), Communication and the Transformation of Economics: Essays in İnformation, Public Policiy and Political Economy, Westview Press, Oxford.

Başaran, Funda (2005), Ağ Ekonomisi ve İnternet, (Editöreler), Funda Başaran ve Haluk Geray. İletişim Ağlarının Ekonomisi: Telekomünikasyon, Kitle İletişimi, Yazılım ve İnternet, Ankara: Siyasal Kitapevi, s.237-257.

Berki, Ahmetcan (2019), "Dijital Pazarlama Uygulamalarının Satış ve Marka Bilinirliğini Arttırmaya Yönelik Etkisinin Değerlendirilmesi”, Egemia Ege Üniversitesi İletişim Fakültesi Medya ve İletişim Araştırmaları Hakemli E-Dergisi, 5, ss. 136- 170.

Bolin, Göran (2011), Value and the Media: Cultural Production and Consumption in Digital Markets, Ashgate Publishing, Farnham and Burlington.

Burston, Jonathan, Dyer-Witherford, Nick Ve Hearn, Alison (2010), "Digital Labour: Workers, Authors, Citizens", Ephemera, 10(3-4) p. 214-221.

Cleland, Scott ve Brodsky, Ira (2011), Search \& Destroy: Why You Can’t Trust Google Inc., Telescope Books, St. Louis.

Cohen, Nicole (2008), "The Valorization of Surveillance: Towards a Political Economy of Facebook", Democratic Communique, 22(1), p.5-22.

Cote, Mark ve Pybus, Jennifer (2010), "Learnig to İmmaterial Labour 2.0: Myspace and Social Networks", Ephemera, 7(1), p. 88-106. 
Cote, Mark ve Pybus, Jennifer (2011). Cognitive Capitalism, Education and Digital Labor, Peter Lang International Academic Publishers, New York.

Çalişkan, Behlül (2009), "Enformasyonun Metalaşması Üzerine”, Marmara Dergisi 15, ss.2346.

Çetin, Beyzade Nadir (2019), “Üretüketim Olgusu Bağlamında Örtülü Emek Olarak Dijital Üretüketici Emeği”, Sosyal Siyaset Konferansları Dergisi, 77, ss.349-382.

Doyle, Gillian (2002), Understanding Media Economics, Publications, London.

Dyer-Witheford, Nick (1999), Cyber-Marx: Cycles and Circuits of Struggle in HighTechnology Capitalism, University of Illlinois Press, Urbana.

Ekman, Mattias (2019), Birikimi Anlamak Marx'ın İlkel Birikim Kuramının Medya ve İletişim Çalışmaları Açısından Önemi, (Editörler), Vincent Mosco ve Christian Fuchs. Funda Başaran (çev), Medya, Meta ve Sermaye Birikimi: Marx Geri Döndü, Ankara: NotaBene Yayınlar1, s. 83-113.

Fortunati, Leopoldina (2007), “The Mobile Phone: Towards New Categories and Social Relations", Information, Communication \& Society, 5(4), p.513-528.

Fuchs, Christian (2015), Dijital Emek ve Karl Marx, Senem Oğuz ve Tahir Emre Kalaycı (çev), NotaBene Yayınları, Ankara.

Fuchs, Christian (2016), Sosyal Medya: Eleştirel Bir Giriş, Diyar Saraçoğlu ve İlker Kalaycı (çev), NotaBene Yayınları, Ankara.

Fuchs, Christian (2019), Marx Geri Döndü: Medya, Meta ve Sermaye, (Editörler), Christian Fuchs ve Vincent Mosco. Funda Başaran (çev), NotaBene Yayınları, Ankara.

Garnham, Nicholas (1990), Capitalismand Communication, SAGE Publications, London.

Garnham, Nicholas (2000), Emancipation, the Media and Modernity: Arguments about the Media and Social Theory, Oxford University Press, Oxford.

Gelernter, David (1993), Mirror World, Oxford University Press, ABD.

Gilder, George (2019), Google Sonrası Yaşam: Büyük Verinin Düşüşü ve Blokzincir Ekonomisinin Yükselişi, Nalan Kurunç (çev), A7 Kitap Yayıncılık, İstanbul.

Hard, Michael ve Negri, Antonio (2002), İmparatorluk, Abdullah Yılmaz (çev), Ayrıntı Yayınları, İstanbul.

Hard, Michael ve Negri, Antonio (2004), Çokluk, Barış Yıldırım (çev), Ayrıntı Yayınları, İstanbul.

Haug, Wolfgang Fritz (2009), Immaterial Labour. Joseph Fracchia (çev), Historical Materialism, 17(1), p. 177-185. 
Hyde, Lewis (2008), Armağan: Sanatsal Yaratılık Dünyayı Nasıl Değiştirir?, Emine Ayhan (çev), Metis Yayınları, İstanbul.

Jhally, Sut, (1987), The Codes of Advertising, Routledge, New York.

Kapanadze, Dilek (2019), "Vygostky’nin Sosyo- Kültürel ve Bilişsel Gelişim Teorisi Bağlamında Türkçe Öğretiminin Değerlendirilmesi”, Sdü Fen-Edebiyat Fakültesi Sosyal Bilimler Dergisi, 47, ss. 181- 195.

Kıyan, Zafer (2015), “Dijital Kapitalizm’in İletişim Alanındaki İzleri: Üretim, Dolaşım, Emek ve Tüketim Süreçleri”, Toplum ve Bilim Dergisi, 135, ss.27-56.

Landes, William (2011), Copyright, (Editör), Ruth Towse. A Handbook of Cultural Economics, Cheltenham: Edward Elgar Publishing, p.100-112.

Lazzarato, Maurizio (1996), Immaterial Labor, (Editörler), Paolo Virno ve Micheal Hardt, Minneapolis From Radical Thought in Italy: A Potential Politic, Minneapolis: University of Minnesota Press, p.133-150.

Levy, Steven (2011), In The Plex: How Google Thinks, Works and Shapes Our Lives, Simon\&Schuster, New York.

Lyon, David (2006), Gözetlenen Toplum: Günlük Hayatı Kontrol Etmek, Gözde Soykan (çev), Kalkedon Yayınları, İstanbul.

Manzerolle, Vincent ve Kjøsen, Atle Mikkola (2019), Sermayenin İletişimi: Sayısal Medya ve Hızlanmanın Mantığı. (Editörler), Vincent Mosco ve Christian Fuchs. Funda Başaran (çev), Medya, Meta ve Sermaye Birikimi: Marx Geri Döndü, Ankara: NotaBene Yayınları, s.217-246.

Manzerolle, Vincent ve Smeltzer, Sandra (2011), "Consumer Databases and the Commercial Mediation of İdentity: A Medium Theory Analysis", Surveillance and Society, 8(3). p.323-372.

Marx, Karl (1978), Capital: A Critique of Political Economy Volume, David Fernbach (çev), Penguin, London.

Marx, Karl (2015), Kapital: 1.Cilt, Mehmet Selik (çev), Yordam Kitap, İstanbul.

Mies, Maria (1986). Patriarchy\& Accumulation on a World Scale: Women in the İnternatioanl Division of Labour, Zed Books, London.

Mosco, Vincent (1988), Introduction: Information in the Pay-per Society, (Editörler) Vincent Mosco ve Janet Wasko. Political Economy of Information, Madison: The University of Wisconsin Press, p.3-26.

Mosco, Vincent (2009), The Political Economy of Communication, Sage Publications, London. 
Murdock, Graham (2011), Political Economies as Moral Economies: Commodities, Gifts and Public Goods, (Editörler), Janet Wasko, Graham Murdock ve Helena Sousa. The Handbook of Political Economy of Communication, Oxford: Blackwell Publishing, p.1140 .

Özmakas, Utku (2015), “İnsan Sermayesinin Kaynağı: Maddi Olmayan Emek”, Toplum ve Bilim Dergisi, 135, ss. 8-26.

Ritzer, George ve Rey, Patella (2016), From 'Solid' Producers and Consumers to 'Liquid' Prosumers, (Editör), Mark Davis. Liquid Sociology: Metaphor in Zygmunt Bauman's Analysis of Modernity, New York: Routledge Publishing, p.157-176.

Ryan, Bill (1992), Making Capital from Culture: The Corporate From of Capitalist Production, Walter de Gruyter, New York.

Sandoval, Marisol (2012), A Critical Empirical Case Study of Consumer Surveillance on Web 2.0, (Editörler), Christian Fuchs, Kees Boersma, Anders Albrechtslund, ve Marisol Sandoval. Internet an Surveillance: The Challenges of Web 2.0 and Social Media, New York: Routledge, s.147-169.

Saraçoğlu, Diyar (2015), Önsöz, Sömürünün Yeni ve 'Sevimli’ Yüzü: Dijital Emek. Senem Kalaycı ve Tahir Emre Oğuz (çev), Dijital Emek ve Karl Marx, İstanbul: Nota Bene Yayınları, s.11-16.

Schiller, Herbert (1991), The Cultere, Inc.: The Corporate Takeover of Public Expression, Oxford University Press, New York.

Smythe, Dallas (1982), On the Audience Commodity and its Work, (Editörler), Meenakshi Gigi Durham ve Douglas Keller Media and Cultural Studies Keywords, New Jersey: WileyBlackwell, p.230-256.

Stiegler, Bernard (2010), For a New Critique of Political, Cambridge Polity Press, Cambridge. Straw, Will (2000), "Music as Commodity and Material Culture”, Repercussions, 7(8), p.147171.

Stross, Randall (2008), Planet Google: One Company’s Audacious Plan to Organize Everything We Know, New York, Free Press.

Terranova, Tiziana (2000), "Free Labor: Producing Culture fort he Digital Economy”, Social Tex, 18(2), p.33-58.

Thompson, John (2008), Medya ve Modernite, Serdar Öztürk (çev), Kırmızı Yayınları, İstanbul.

Uca, Onur (2018), “İtalyan İşçi Sınıfı Deneyimi ve Kapitalist Bireyciliğin Sıradanlaşması”, Atatürk Üniversitesi Sosyal Bilimler Enstitüsü Dergisi, 22 (2), ss.1139-1156. 
Vise, David ve Malseed, Mark (2005), The Google Story, Macmillan, London.

Wasco, J. (2005). Studying the Political Economy of Media and Information. Comunicação e Sociedade, 7 , p. 25-48.

Winseck, Dwayne (2011), The Political Economies of Media: The Transformation of the Global Media Industries, (Editörler), Dwayne Roy Winseck ve Dal Yong Jin. The Political Economies of Media: The Transformation of the Global Media İndustries, London: Bloomsbury Academic, p.2-48.

Zwick, Detlev, Bonsu Samuel ve Darmody Aron (2009), "Putting Consumers to Work: "Cocreation" and New Marketing Governmentality", Journal of Consumer Culture, 8(2), p.163-196.

\section{Internet Kaynakları}

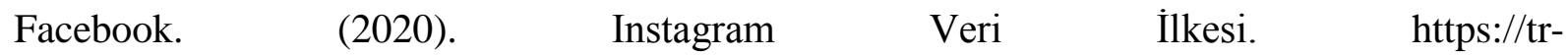
tr.facebook.com/help/instagram/519522125107875 adresinden alınmıştır.

Google. (t.y.). Çalışma Şeklimiz. Aralık 14, 2020 tarihinde, https://about.google/intl/tr_TR/how-our-business-works/ adresinden alınmıştır.

Google. (t.y.). Kendiniz İçin Uygun Bütçe Belirleyin. Aralık 16, 2020 tarihinde, https://ads.google.com/intl/tr_tr/home/pricing/ adresinden alınmıştır.

Google. (t.y.). Kişisel Bilgilerinizi Hiç Kimseye Satmayız. Aralık 12, 2020 tarihinde https://safety.google/privacy/ads-and-data/ adresinden alınmıştır.

Google. (2020). Google Arama Ağı Hakkında. https://support.google.com/googleads/answer/1722047?hl=tr adresinden alınmıştır.

Google. (2020). Görüntülü Reklamlar ve Google Görüntülü Reklam Hakkında. https://support.google.com/google-ads/answer/2404190 adresinden alınmıştır.

Google. (2020). YouTube Reklamları Hakkında. https://support.google.com/googleads/answer/6052202?hl=tr adresinden alınmıştır.

Google. (2020). Gmail Reklamları Hakkında. https://support.google.com/googleads/answer/7019460?hl=tr adresinden alınmıştır.

Google. (2020). Yeniden Pazarlama Kampanyaları Oluşturmak İçin Google Ads Editor'1 Kullanma. $\quad$ https://support.google.com/google-ads/answer/7067580?hl=tr adresinden alınmıştır.

Google. (t.y.). Merchant Center. Aralık 11, 2020 tarihinde, https://www.google.com/intl/tr_tr/retail/solutions/merchant-center/ adresinden alınmıştır. 
Kişisel Verileri Koruma Kurumu. (2018). Kişisel Verilerin Korunması Alanında Uluslararası ve Ulusal Düzenlemeler. https://www.kvkk.gov.tr/Icerik/4183/Kisisel-Verilerin-KorunmasiAlaninda-Uluslararasi-ve-Ulusal-Duzenlemeler adresinden alınmıştır.

Magna Dijital. (t.y.). Google Analytics Nedir? Nasıl Kullanılır?. Aralık 20, 2020 tarihinde, https://www.magnadijital.com.tr/blog/dijital-pazarlama/google-analytics-nedir-nasil-kullanilir adresinden alınmıştır. 